Uluslararası Sosyal Bilgilerde Yeni Yaklaşımlar Dergisi, 2021, 5(1), 98-118

International Journal of New Approaches in Social Studies, 2021, 5(1), 98-118

\title{
Fransa Ders Kitaplarında Yer Alan Görsellerin Toplumsal Cinsiyet Rolleri Bağlamında İncelenmesi: Ortaokul Tarih ve Coğrafya Dersi Örneği*
}

\author{
İlyas KARA ${ }^{1}$ (D), Veysi AKTAŞ² (D) \& Tuğba YAMAN ${ }^{3 * *}(\mathbb{D})$
}

Gönderilme Tarihi: 02 Mayı $2021 \quad$ Kabul Tarihi: 20 Mayıs 2021

DOI: $10.38015 /$ sbyy. 931674

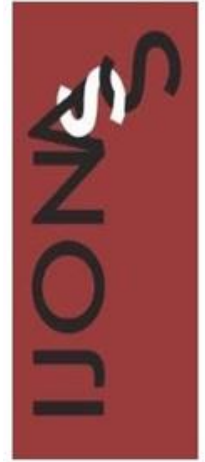

\begin{abstract}
$\ddot{O} z:$
Okullar toplumsal cinsiyet rollerinin güçlenmesinde veya zaylflamasında büyük bir etkiye sahiptir. Okullar toplumun beklentilerine yönelik hedeflerin öğrencilere kazandırılması amacıyla çeșitli yöntem, teknik ve araçlar kullanır. Bu araçlardan birisi de ders kitaplarıdır. Öğrencide cinsiyet rollerinin oluşmasında ders kitaplarının da etkisi söz konusudur. Bu bağlamda çalışmanın temel amacl, Fransa ortaokul (college) tarih ve coğrafya ders kitaplarında toplumsal cinsiyet rollerinin işlenişini ve cinsiyet rollerine bağlı olarak meslek gruplarında farklılaşmanın olup olmadığını belirlemektir. $\mathrm{Bu}$ amaç doğrultusunda araştırmada nitel araştırma yöntemlerinden doküman incelemesi yöntemi kullanılmıştır. Ortaokul tarih ve coğrafya ders kitaplarında yer alan görseller kadın-erkek rolleri, anne-baba rolleri ve mesleki roller açısından incelenmiștir. Anne-baba rolleri; çocuk bakımı, ev içi sorumluluklar ve ev dışı sorumluluklar bağlamında incelenirken mesleki roller; kadın, erkek ve kadın-erkeğe biçilen mesleki roller bağlamında incelenmiştir. Elde edilen veriler içerik analiz tekniği ile çözümlenmiştir. Araştırma sonucunda aile içinde kadınların daha fazla ev içi sorumluluklarla ilişkilendirildiği, çocuk bakımı ile ilgilendiği, ev dışında da çocuklarla, mutfakla bă̆lantılı olabilecek sorumlulukların olduğu; erkeklerin ise daha çok güç ve otorite isteyen görevlerde olduğu görülmektedir. Mesleki rollerde de kadın ve erkek rollerinde farklılıklar olduğu yönündedir. Kadınlar daha çok ögretmen, bankacı ve hemşire gibi meslekler ile ilişkilendirilmiştir. Erkekler ise hem güç ve otoriteyle birleşen hem de kadınlara oranla çok daha çeşitli mesleki kollarda roller verilmiştir. Erkekler çiftçi, şoför, mühendis, mimar, sporcu, bilim adamı ve politikacı gibi mesleklerle ilişkilendirilmişlerdir. Bunun yanı sıra Fransa ortaokullarında okutulan tarih ve coğrafya ders kitaplarının tarih, coğrafya, ahlak ve vatandaşlık eğitimi konularını kapsadı̆̆ görülmüştür. Tarih ve coğrafya konularının yer aldiğı bölümlerde toplumsal cinsiyet rollerindeki ayrımın daha belirgin olduğu saptanmıştır. Bu bölümlerde yer alan görsellerde daha çok erkeklerin yer aldı̆̆ belirlenmiştir. Ahlak ve vatandaşlık ĕgitiminin yer aldı̆̆ bölümlerde ise toplumsal cinsiyet ayrımının daha az olduğu belirlenmiş olup bu durumun hedeflenen kazanımlarla ilgili olduğu sonucuna ulaşılmıştır.
\end{abstract}

Anahtar Kelimeler: Fransa, toplumsal cinsiyet rolleri, tarih ve coğrafya, ders kitabl.

Abstract:

Schools have a major impact on strengthening or weakening social gender roles.

\footnotetext{
${ }^{1}$ Marmara Üniversitesi, Türkiye. Orcid ID: 0000-0003-4755-0037

${ }^{2}$ Marmara Üniversitesi, Türkiye. Orcid ID: 0000-0002-5174-7505

${ }^{3}$ Marmara Üniversitesi, Türkiye. Orcid ID: 0000-0002-3283-8989

*Bu çalışma, 10-11 Nisan 2021 tarihlerinde düzenlenen Uluslararası Sosyal Bilimler ve Eğitim Bilimleri Sempozyumu'nda sözlü bildiri olarak sunulmuştur.

${ }^{* *}$ SorumluYazar (Corresponding Author): tugbayaman60@gmail.com
} 
Schools use various methods, techniques and tools in order to gain students the goals of society's expectations. One of these tools is textbooks. Textbooks have a great effect on the formation of gender roles in students. In this vein, the main objective of study is to find out how the gender roles are represented and if there is a differentiation in occupational groups depending on the gender roles in France middle school history and geography coursebooks. In line with this objective document analysis of qualitative research methods is carried out in this study. The visuals in middle school history and geography coursebooks have been examined in terms of gender roles, parental roles and occupational roles. While parental roles have been examined in terms of childcare, responsibilities indoors and out; occupational roles have been examined in terms of roles found suitable for woman, man and woman-man. The obtained data has been analysed with the method of content analysis. As a result of the study, it has been understood that women are more associated with the responsibilities indoors and interested in childcare, have responsibilities about cooking out; men are associated with the responsibilities requiring discipline and power. In terms of occupational roles genders have differences. Women are more associated with occupations such as teacher, bank employee and nurse. Whereas men are given roles in the fields of occupation both requiring discipline and power and various in proportion to women. Men are associated with the occupations such as farmer, driver, engineer, architecture, athlete, scientist and politician. Besides, it has been realised that history and geography coursebooks taught in french middle schools include topics of history, geography and citizenship education. It has been determined that social gender apartheid is more evident in sections including the topics of history and geography. In the visuals of those sections, it has been determined that men appear more. Besides determining that gender apartheid is less in sections including moral and citizenship education, it has been concluded that this situation is related to targeted acquisition.

Keywords: France, social gender apartheid, history and geography, coursebook.

\section{GíRiş}

İnsan sosyal bir varlıktır ve toplum içerisinde yaşar. Birey içerisinde yaşadığı toplumun normlarına uyum sağlayarak sosyalleşir. Bu süreçte birey toplumun kendisinden beklediği davranışları sergilemeyi amaçlar. Bu amacını gerçekleştirdiğinde yaşadığı topluma uyum sağlayarak sosyalleşmiş olur. Aynı toplum içerisinde farklı gruplar yer alabilmektedir. İnsan bu gruplardan herhangi birine dahil olur. Öte yandan insanları, gruplara ayırmak ve farklılaştırmak amaciyla kullanılan niteliklerden biri de cinsiyet değişkenidir. Cinsiyet ise, canlıların cinsiyet kromozomları ile saptanan yapısal, işlevsel ve davranışsal özelliklerini içeren; bireyin kadın veya erkek olarak gösterdiği genetik, biyolojik özellikler ve farklılıklar anlamına gelmektedir (Marshall, 1999; Cheryy, 2005). Toplumsal cinsiyet, kadın ve erkek bireylerin hayat tecrübeleri sonucunda oluşan bir durum olarak görülmektedir (Stoller, 1968). Diğer bir deyişle cinsiyet, kadın veya erkek olmanın fiziksel boyutunu ifade etmekte ve nüfus kategorisi olarak ele alınmaktadır. Toplumsal cinsiyet kavramı ise, toplumun sahip olduğu kültürün, geçmişten bugüne dek süren gelenek ve göreneklerin atfettiği anlamı ve beklentileri içermektedir (Dökmen, 2004).

Cinsiyet ve toplumsal cinsiyet terimleri farklı anlamlara sahip iki kavram olarak değerlendirilmektedir. Bu iki kavram arasındaki farklılıkları Robert J. Stoller 1968 yılında yazdiğ 1 kitapta dile getirmiştir. "Sex and Gender, The Development of Masculunity and Feminity" başlıklı bu kitapta kadın ve erkek farklılığına vurgu yapılmaktadır. Toplumsal cinsiyet kavramının, cinsiyet kavramı gibi doğal bir şekilde oluşmadığı ve toplumlar tarafindan sonradan oluşturulduğu ifade edilmiştir (Stoller, 1968). Toplum, kadın ve erkeği doğuştan getirdiği biyolojik farklılıklara göre değerlendirmiş ve onlardan bu farklılıklara uygun davranışlar sergilemelerini bekleyerek, bireyin sosyalleşme sürecinde onlara yeniden rol ve sorumluluklar atfetmiştir. Atfedilen bu rol ve sorumluluklar toplumdan topluma, zamandan zamana ve mekândan mekâna değişiklik göstermiştir (Scott, 2007). Bunun yanı sıra 
"toplumsal cinsiyet" kavramı, eşitlik fikrinden yola çıkarak ve kadın erkek arasındaki doğal farklardan sıyrılarak dönüşüme açık bir kavram haline gelmiştir.

Toplumsal cinsiyet, kadın ve erkeğin rollerine yönelik beklentileri içermekte ve toplumsal kategorileri belirlemektedir. Toplumsal cinsiyet kadın ve erkeğin nasıl davranması gerektiği konusunda kurallar koymaktadır. Toplumsal cinsiyet kavramının ortaya çıkışında kadın ve erkeğe biçilen roller etkili olmaktadır. Çünkü kadın ve erkek toplumsal cinsiyet rollerini doğuştan öğrenmez, toplum içerisinde zamanla kazanır. Her toplumun gelenek, görenek ve kültürel yapısı farklı olduğundan toplumsal cinsiyet rollerinde farklılıklar görülebilmektedir (Maher \& Ward, 2008).

Cinsiyet özellikleri kavramı yapısal niteliklere dikkat çekerken, cinsiyet rolleri kadın ve erkeklere yönelik sosyal ve kültürel görevleri, nitelendirmeleri göstermektedir. Toplumsal cinsiyet toplumun kadın ve erkeğe atfettiği anlam ve sorumlulukları belirtmektedir. Kadın ve erkeğin hakları, sorumlulukları, toplum içerisindeki durumları toplumsal cinsiyete göre şekil almaktadır (Helvacıoğlu, 1996). Toplum kadın ve erkeklerden bazı duygusal ve davranışsal beklentiler içerisine girmektedir ve onlara birtakım rol ve sorumluluklar yüklemektedir. Biyolojik cinsiyetten farklı olan bu toplumsal cinsiyet kavramı, kadına ve erkeğe toplum içerisinde yüklenen rol ve sorumlulukları ifade etmektedir. Cinsiyete göre değişen bu kalıp yargılar sonradan oluşmuş ve toplumdan topluma farklı özellikler göstermiştir (Dökmen, 2010; Akın \& Demirel, 2003). Her insan birbirinden farklı psikolojik ve fiziksel özellikler barındırmaktadır. Ancak toplumlar bir arada yaşarken kalıp yargılar oluşturma eğilimindedir (Dökmen, 2010). İnsanlar, grupları belirli özelliklere göre sinıflandırarak bir kategori içerisindeki bütün bireylerin aynı niteliklere sahip olduklarını kabul etme eğilimindedirler. İnsanlar kadın ve erkeği farklı gruplar olarak görmekte ve bu konu ile ilgili derin kalıp yargılar oluşturabilmektedirler (Maher \& Ward, 2008). Toplumsal cinsiyetle ilgili kalıp yargılar, toplumun kadın ve erkekten beklediği davranış kalıpları olarak tanımlanabilir. Bu kalıp yargılar cinsiyet rollerine ve cinsiyet özelliklerine ilişkin kalıp yargılardır (Şirvanl1Özen, 1992). Kadın ve erkekle ilgili bu kalıp yargılar bireylere ilk olarak ailede açık ve gizil mesajlar ile öğretilir.

Aile, çocuğun davranışlarını toplumsal kurallar doğrultusunda değerlendirerek ödül ve ceza yöntemi kullanır, çocuğun kadın ve erkeğe yönelik kalıp yargılar geliştirmesine sebep olur (Wortham, 2002). Daha sonra bireyler aileden ve çevreden edindikleri bu bilgileri kendi yaşantılarında kullanırlar. Özellikle toplumsal cinsiyet ile ilgili öğrenmeler bireyin yaşantısını derin biçimde etkiler. Öyle ki öğrenmiş olduğu bu bilgiler onun davranışlarını şekillendirir ve toplumsal cinsiyetle ilgili yargilara uygun davranmasına sebep olur. O kadarki insanlar öğrendikleri bu bilgileri sorgulamadan doğru kabul eder ve bu özelliklerin kadın ve erkeğin doğası ile ilgili olduğunu düşünmeye başlar (Maher \& Ward, 2008; Dökmen, 2010).

Ailenin dışında insanların almış oldukları bilgileri sorgulamadan kabul ettikleri ortamlardan biri de okullardır. Bireylerin okula başlaması ile zamanlarının büyük çoğunluğu okulda geçmektedir. Dolayısı ile okullarda görevli öğretmenler, okutulan ders kitapları, materyaller, aktiviteler ve arkadaşlardan öğrenilen davranışlar cinsiyet kalıp yargılarının pekiştirilmesi veya bunlarla mücadele edilmesi bağlamında çok önemli bir etkiye sahiptir (Maher \& Ward, 2008). Okullar öğrencilerin bilişsel, duyuşsal ve sosyal gelişimlerinde büyük öneme sahiptir. Okulun ilk yıllarında edindikleri en önemli becerilerden birisi de okumadır. Anlamanın bir parçasını oluşturan okuma öğrencilerin düşünme becerilerini geliştirir. Çocukların cinsiyet farkındalığını ve toplumun cinsiyetlere yüklediği rol ve sorumlulukları kitaplar aracılığı ile 
daha derinden kavrar. Öyle ki ders kitaplarında yer alan metinler ve görseller açık veya gizil olarak insanlar arasında cinsiyet farkındalığı içerebilmektedir (Sanford \& Donovan, 1999). Ders kitaplarında yer alan görsellerin ise metinlerden daha etkili olduğu bilinmektedir. Çünkü özellikler okulun ilk yıllarında çocukların dikkatini metinlerden çok görseller çekmektedir (Evans \& Saint-Aubin, 2005). Ders kitapları çocukların cinsiyetlere göre algınlarını şekillendirmektedir. Çünkü öğrenciler sınıfta geçirdikleri zamanın büyük çoğunluğunda ders kitaplarıyla etkileşim halinde olmaktadır. Öğretmenler de sınıftaki eğitim öğretim faaliyetlerinde ders kitaplarını esas almaktadır (Fan \& Kaeley, 2000). Özelikle somut işlemler dönemindeki öğrenciler ders kitabında yer alan bilgileri eleştirmeden ve sorgulamadan kabul etmektedir. Ders kitapları öğrencinin yaşantılarını artırmaya ve bu yaşantıları yorumlamaya aracılık etmektedir. Öğrencinin sosyalleşmesi bağlamında ders kitapları önemli bir yere sahiptir. Ders kitapları toplumsal cinsiyete yönelik bilgilere de yer verir ve bu durum öğrencinin toplumsal cinsiyet rollerini öğrenmesine ve bunu devam ettirmesine aracılık eder. Toplumun kadına ve erkeğe atfetmiş olduğu roller, kadın ve erkek hakkında edinilen önyargılar sorgulanmadığı zaman toplum tarafından yazılan senaryo çocuklar tarafından aktif olarak oynanmaya başlar ve nesilden nesle bu durum devam eder.

Son zamanlarda yurt içinde ve yurt dışında yapılan çalışmalar, ders kitaplarında cinsiyetlere yönelik yanlı içerik ve önyargılar barındırdığını göstermektedir (Blumberg, 2008). Bu sorun dünya genelinde oldukça yaygın olmakla birlikte eğitim sistemlerinde çoğunlukla görmezden gelinmektedir. Bu nedenle toplumsal cinsiyet eşitsizliği eğitim sistemlerinin başlıca sorunları arasında yer almaktadır. Bu eşitsizliğin en somut biçimde görüldüğü alanlardan birisi ise ders kitaplarıdır. Ders kitaplarında yer alan içerikler incelendiğinde kadın ve erkek arasındaki eşitsizlikler göze çarpabilmektedir (Blumberg, 2008).

Konuyla ilgili yapılan çalışmalar (Tezer-Asan, 2010; Kırbaşoğlu-Kılıç \& Eyüp, 2011; Barton \& Sakwa, 2012; Táboas-Pais \& Rey-Cao, 2012; Yıldız, 2013; Güney, 2016; Sarıtaş \& Şahin, 2018; Satılmış, 2019; Özdemir \& Balc1-Karabaoğa, 2019) incelendiğinde ders kitaplarında cinsiyet ayrımına yönelik yargıların genellikle benzer özellikler taşıdığı görülmektedir. Kitaplarda yer verilen resimlerde ve metinlerde kadınlar daha çok yemek ve temizlik yapma gibi ev işlerini yerine getirmekte veya çocuk bakımıyla ilgili görevlerini üstlenmektedir. Görsellerde kadın figürlerin elinde genellikle bebek, mutfak aletleri, temizlik malzemeleri gibi çoğunlukla evle ilgili malzemeler yer alırken; erkek figürlerin elinde ise genellikle ev dışındaki işlerde kullanılan malzemeler yer almaktadır. Oyun içeren resimlerde kız çocuklarının oyuncak bebekle evcilik oynarken resmedilmesi, kadına biçilen çocuğa bakma ve annelik rolünün edindirilmesi amacı ile ilgilidir. Erkek çocuklarının kılıçla, topla ve sokak oyunlarını oynaması ise onların daha güçlü, savaşçı ve saldırgan olmaya yönelik kişilik özelliklerinin geliştirilmesi hedeflenmektedir. Kitaplarda yer alan toplumsal cinsiyete ilişkin kalıp yargılardan bir diğeri ise meslek seçimine yöneliktir. Ders kitaplarında kadın karakterlerin hem resimlerde hem de metin içlerinde genellikle öğretmenlik hemşirelik ve sosyal danışman gibi daha fazla diğerlerine bakmaya yönelik meslekleri yerine getirirken, erkek karakterlerin ise kadınlara göre daha geniş yelpazede çeşitli meslekleri yerine getirirken gösterildiği görülmektedir. Sanat, bilim, sağlık alanı, politika gibi alanlarında erkeklere, eğitim alanında ise kadınlara daha fazla yer verilmektedir (Şeker \& Dinçer, 2014). Bu durum öğrencide cinsiyet rollerinin oluşmasında ders kitaplarının önemli bir etkisinin olduğunu göstermektedir. Çünkü öğretmen sınıftaki eğitim öğretim faaliyetlerinde ders kitabını esas alır ve öğrenci sınıf içerisindeki zamanının büyük bölümünde ders kitabından yararlanır. $\mathrm{Bu}$ bağlamda ders kitapları, çocuğun gelişiminde ve toplumsal cinsiyet rollerini kazanmasında etkili olmaktadır. $\mathrm{Bu}$ öneminden dolayı bu araştırmada söz konusu ders kitaplarının 
I. $K A R A$,

V. $A K T A S ̧ \&$

T. YAMAN

Fransa Ders Kitaplarında Yer Alan Görsellerin Toplumsal

incelenmesi ve konuya ilişkin olumlu ya da olumsuz durumların belirlenmesi amaçlanmaktadır.

\section{Araştırmanın Amacı}

Okullar toplumsal cinsiyet rollerinin güçlenmesinde veya zayıflamasında büyük bir etkiye sahiptir. Okullar toplumun beklentilerine yönelik hedeflerin öğrencilere kazandırılması amacıyla çeşitli yöntem, teknik ve araçlar kullanır. Bu araçlardan birisi de ders kitaplarıdır. Öğrencide cinsiyet rollerinin oluşmasında ders kitaplarının da etkisi söz konusudur. Konuyla ilgili yapılan çalışmalar incelendiğinde, ders kitaplarında cinsiyet ayrımına yönelik yargılar ile sıklıkla karşılaşıldığı görülmektedir. $\mathrm{Bu}$ durum öğrencilerin toplumsal cinsiyet rollerini kazanma sürecinde olumsuz bir etkiye neden olmaktadır. Tüm bu bilgiler ışığında, toplumsal cinsiyet rolleri bağlamında ders kitaplarının değerlendirilmesi önemli görülmektedir. Farklı ülkelerin bu konudaki durumunun ve tutumunun araştırılarak incelenmesinin de ilgili alan yazına katkıda bulunması düşünülmektedir. Bu bağlamda araştırmanın amacı, Fransa ortaokul tarih ve coğrafya ders kitaplarında toplumsal cinsiyet rollerinin işlenişini ve cinsiyet rollerine bağlı olarak meslek gruplarında farklılaşmanın olup olmadığını belirlemektir. Fransa'nın 1789 İhtilali'nden sonra eşitlik, özgürlük, adalet ve demokrasi gibi kavramların dünya çapında yayılmasında öncü olması, araştırmada bu ülkenin tercih edilme nedeni olarak belirtilebilir. Bu sebeple demokrasi ve insan hakları alanında önemli katkıları olan Fransa'nın ortaokul tarih ve coğrafya ders kitaplarında toplumsal cinsiyet rolleri bağlamındaki durumunun incelenmesi önemli görülmektedir.

\section{YÖNTEM}

Bu bölümde araştırmanın modeli, örneklemi, verilerin toplanması ve çözümlenmesine ilişkin bilgilere yer verilmiştir.

\section{Araştırmanın Modeli}

Fransa ortaokul tarih ve coğrafya ders kitaplarında yer alan görsellerin toplumsal cinsiyet rolleri bağlamında incelenmesi amacına yönelik gerçekleştirilen bu çalışma, nitel araştırma yöntemlerine uygun olarak yürütülmüştür. Araştırmanın modeli ise doküman analizi olarak tasarlanmıştır. Doküman analizi, araştırılması amaçlanan olgu ve olaylara ilişkin bilgileri ihtiva eden yazılı ya da görsel malzemelerin incelenmesine olanak sağlayan bir yöntemdir (Yıldırım \& Şimşek, 2013).

\section{Örneklem}

Araştırmanın örneklemini Fransa'da 2020-2021 eğitim-öğretim yılında okutulmakta olan ortaokul 5., 6., 7. ve 8. sınıf tarih ve coğrafya ders kitapları oluşturmaktadır. Bu ders kitapları tarih, coğrafya ve vatandaşlık konularını içermektedir. Ortaokulun tüm kademelerinde okutulan tarih ve coğrafya ders kitaplarında yer alan görsellerin tamamı incelenmiştir. Toplamda dört ders kitabı incelenmiş olup söz konusu kitaplara ilişkin bilgiler Tablo 1'de yer almaktadır. 
I. $K A R A$,

V. $A K T A S ̧ \&$

T. YAMAN

Fransa Ders Kitaplarında Yer Alan Görsellerin Toplumsal Cinsiyet Rolleri Bağlamında Incelenmesi: Ortaokul Tarih ve Coğrafya Dersi Örneği

Tablo 1. Toplumsal Cinsiyet Rolleri Bağlamında İncelenen Ders Kitapları

\begin{tabular}{lllll}
\hline Kitabın Yazarı & Yayım Yılı & Sı́ıf Düzeyi & Kitabın Adı & Yayınevi \\
\hline Collectif & 2019 & 6é (5. Sınıf) & Histoire et Geographie & Nathan Maison d'edition \\
Collectif & 2019 & 5é (6. Sınıf) & Histoire et Geographie & Nathan Maison d'edition \\
Collectif & 2019 & 4é (7. Sınıf) & Histoire et Geographie & Nathan Maison d'edition \\
Collectif & 2019 & 3é (8. Sınıf) & Histoire et Geographie & Nathan Maison d'edition \\
\hline
\end{tabular}

\section{Veri Toplama Teknikleri}

Nitel araştırma yaklaşımın benimsendiği bu çalışmada veriler doküman incelemesi yoluyla toplanmıştır. Doküman incelemesi, araştırılması hedeflenen olgu veya olgular hakkında bilgi içeren yazılı ya da görsel materyallerin analizini kapsamaktadır (Yıldırım \& Şimşek, 2013). Dokümanlar, nitel araştırmalarda üçüncü ana veri toplama kaynağı olarak toplumsal kayıtlar, bireysel yazılar, popüler kültür dokümanları, görsel dokümanlar ve fiziki materyallerle, sanat eserleri olarak tanımlanır. Her tür doküman, anlamın ortaya çıkması, belirsizliklerin ortadan kalkması ve problem sorusu ile ilgili içgörünün keşfedilmesinde araştırmacıya yardımcı olur (Merriam, 2013). Bu bağlamda araştırmada, fiziksel materyallerden ders araç gereci olarak kullanılan Fransa ortaokul 5., 6., 7., ve 8. sınıf tarih ve coğrafya ders kitapları incelenmiş ve bu ders kitaplarında yer alan görseller de görsel dokümanlar olarak incelenmiştir.

\section{Verilerin Analizi}

Araştırmada doküman incelemesi yoluyla toplanan verilerin çözümlenmesinde içerik analizi tekniği kullanılmıştır. İçerik analizinde temel amaç, toplanan verileri açıklayabilecek kavramlara ve ilişkilere ulaşmaktır. İçerik analizi, toplanan verilerin derinlemesine analiz edilmesini gerektirir ve önceden belirgin olmayan temaların ve boyutların ortaya çıkarılmasına olanak sağlar. Bu araştırmanın analiz sürecinde; ders kitaplarında yer alan görsellerin, araştırma konusuyla ilişkili olan belirli kriterler çerçevesinde, değerlendirilmesi ve okuması yapılmış, kodlara ve birbiri ile ilişkili kategorilere ayrılmış daha sonra da ilgili temalara ulaşılarak bu temaların düzenlemesi yapılmıştır (Yıldırım \& Şimşek, 2013). Ders kitaplarında yer alan görseller her üç araştırmacı tarafından birbirinden bağımsız olarak analiz edilmiş ve değerlendirilmiştir. Araştırmacılar arasındaki güvenirlik hesaplaması Miles \& Huberman'ın (1994) güvenirlik formülü referans alınarak yapılmıştır. Yapılan hesaplamaya göre araştırmacılar arasında \% 95 oranında görüş birliğinin olduğu tespit edilmiş ve araştırma analizinin güvenilir olduğu kabul edilmiştir.

\section{BULGULAR VE YORUM}

Bu bölümde, Fransa ortaokul 5., 6., 7. ve 8. sinıflarda okutulan tarih ve coğrafya ders kitaplarında yer alan görsellerde toplumsal cinsiyet rollerinin işlenişi ve cinsiyet rollerine bağlı olarak meslek gruplarında farklılaşmanın olup olmadığına ilişkin elde edilen bulgular ve bu bulgulara ait yorumlar yer almaktadır. Tarih ve coğrafya ders kitaplarında toplumsal cinsiyet rolleri; kadın-erkek rolleri, anne-baba rolleri ve mesleki roller bakımından incelenmiştir. Bu bağlamda ders kitaplarında yer alan görsellerde kadın ve erkeğe atfedilen meslekler Tablo 2 ve Tablo 3 'te hem frekans (f) olarak hem de yüzde (\%) olarak verilmiştir. 
I. $K A R A$,

V. $A K T A S ̧ \&$

T. YAMAN

Fransa Ders Kitaplarında Yer Alan Görsellerin Toplumsal Cinsiyet Rolleri Bağlamında Incelenmesi: Ortaokul Tarih ve Coğrafya Dersi Örneği

Tablo 2. Ortaokul 5., 6., 7. ve 8. Sinıflar Tarih ve Coğrafya Ders Kitaplarındaki Görsellerde Kadın Cinsiyetine Atfedilen Meslek Rolleri

\begin{tabular}{lll}
\multicolumn{1}{c}{ Meslekler } & K & Kadın \\
\hline Sosyal Danışman & 1 & $\%$ \\
Sekreter & 3 & 100 \\
Ev Hanımı & 17 & 100 \\
Öğretmen & 6 & 100 \\
Aktivist & 5 & 86 \\
Arkeolog & 2 & 71 \\
Hemşire / Ebe & 2 & 67 \\
Esnaf & 1 & 67 \\
\hline
\end{tabular}

Tablo 2 incelendiğinde, Fransa ortaokul 5., 6.,7. ve 8. sinıflarda okutulan tarih ve coğrafya ders kitaplarında yer alan görsellerin mesleki roller bağlamında incelenmesi sonucunda, görsellerin bazılarında çoğunlukla kadın cinsiyetine atfedilen mesleklerin olduğu görülmektedir. Öyle ki, bu görsellerde sosyal danışmanlık mesleğine yer veren sadece 1 tane görselin olduğu ve bu mesleğin kadına atfedildiği görülmüştür. Böylece ders kitaplarında yer alan sosyal danışmanlık mesleğinin \%100'ünü kadın cinsiyetinin temsil ettiği belirlenmiştir. Bunun yanı sıra, ders kitaplarında yer alan görsellerin 3'ünde sekreterlik mesleğine yer verilmiş ve her 3 görselde de bu mesleği icra eden cinsiyetin kadın olduğu tespit edilmiştir. Böylece ders kitaplarında yer alan görsellerde sekreterlik mesleği \%100 oranında kadın cinsiyetine atfedilmiştir. İncelenen görsellerin 17'sinin ise ev işleriyle ilgili olduğu ve bu görsellerin 17'sinde (\%100) ev işlerinin kadın tarafından yapıldığ 1 görülmüştür. Tarih ve coğrafya ders kitaplarında öğretmenlik mesleğine yer veren görsellerin \%86'sında ( $\mathrm{f}=6)$ bu mesleği icra eden cinsiyetin kadın olduğu belirlenmiştir. Aktivistlere yer verilen görsellerin \%71'inde ( $\mathrm{f}=5)$ ise kadın cinsiyetine yer verildiği görülmüştür. Ayrıca incelenen görsellerde arkeolog ve hemşire/ebe olarak gösterilen kişilerin çoğunluğunun kadın olduğu (\%67) saptanmıştır. Esnaflık mesleği ile ilişkili görsellerde ise kadın ve erkek oranının eşit olduğu (\%50) gözlemlenmiştir. Tablo 2'de de görüldüğü gibi ev işleri, bakım ve gözetim gibi mesleklerin çoğunlukla kadına atfedildiği görülmüştür.

Tablo 3. Ortaokul 5., 6., 7. ve 8. Sınıflar Tarih ve Coğrafya Ders Kitaplarındaki Görsellerde Erkek Cinsiyetine Atfedilen Meslek Rolleri

\begin{tabular}{lll}
\hline \multicolumn{1}{c}{ Meslekler } & F & Erkek \\
\hline Balıkçı & 2 & $\%$ \\
Çoban & 3 & 100 \\
Hizmetli & 2 & 100 \\
Doktor & 1 & 100 \\
Şoför & 4 & 100 \\
İtfaiye & 3 & 100 \\
Asker/Polis & 12 & 100 \\
Politikacı & 19 & 80 \\
Çiftçi & 10 & 73 \\
Bilim İnsanı/Düşünür & 12 & 71 \\
Sanatçı & 8 & 67 \\
Avukat/Yargıç & 4 & 67 \\
Mühendis & 2 & 67 \\
Sporcu & 2 & 67 \\
İşçi & 4 & 67 \\
Esnaf & 1 & 57 \\
\hline
\end{tabular}


I. $K A R A$,

V. $A K T A S ̧ \&$

T. YAMAN

Fransa Ders Kitaplarında Yer Alan Görsellerin Toplumsal

Tablo 3 incelendiğinde, Fransa ortaokul 5., 6.,7. ve 8. sinıflarda okutulan tarih ve coğrafya ders kitaplarında yer alan görsellerin mesleki roller bağlamında incelenmesi sonucunda, görsellerin bazılarında çoğunlukla erkek cinsiyetine atfedilen mesleklerin olduğu görülmektedir. Söz konusu görsellerde balıkçı $(\mathrm{f}=2)$, çoban $(\mathrm{f}=3)$, hizmetli $(\mathrm{f}=2)$, doktor $(\mathrm{f}=1)$, şoför $(\mathrm{f}=4)$, itfaiye $(\mathrm{f}=3)$ gibi mesleklerin \%100'ünü icra eden kişilerin erkek cinsiyeti olduğu görülmektedir. Asker ve polis olarak yer verilen cinsiyetin de \%80'inin ( $\mathrm{f}=12$ ) erkek olduğu belirlenmiştir. Politikacı olarak gösterilen cinsiyetin \%73'ünün $(\mathrm{f}=19)$ ve çiftçi olarak gösterilen cinsiyetin \%71'inin ( $\mathrm{f}=10)$ erkek olduğu belirlenmiştir. Bunun yanı sira bilim insanı/ düşünür, sanatçı, avukat/yargıç, mühendis ve sporcu gibi mesleklerin yer verildiği görsellerin \%67'sini erkek cinsiyetinin temsil ettiği görülmüştür. İşçi mesleğine yer verilen görsellerde ise $\% 57$ oranında erkek cinsiyetinin ön planda olduğu saptanmıştır. Tablo 2 ve Tablo 3'te yer verildiği gibi esnaflık mesleğini icra eden figürlerin kadın ve erkek cinsiyeti bağlamında eşit $(\% 50)$ olduğu belirlenmiştir. Tablo 3 'te de görüldüğü gibi güç ve otorite isteyen meslekler ile dişa dönük mesleklerin daha çok erkeğe atfedildiği belirlenmiştir.

Araştırmada toplam dört ders kitabı incelenmiş olup söz konusu görseller ve bu görsellere ait bulgu ve yorumlar aşağıda yer almaktadır.

\section{Fransa Ortaokul Tarih ve Cŏgrafya Ders Kitaplarında Yer Alan Görsellerde Kadın Cinsiyeti ile İlişkilendirilen Cinsiyet Rolleri ve Mesleki Rollere İlişkin Görseller ve Bulgular}

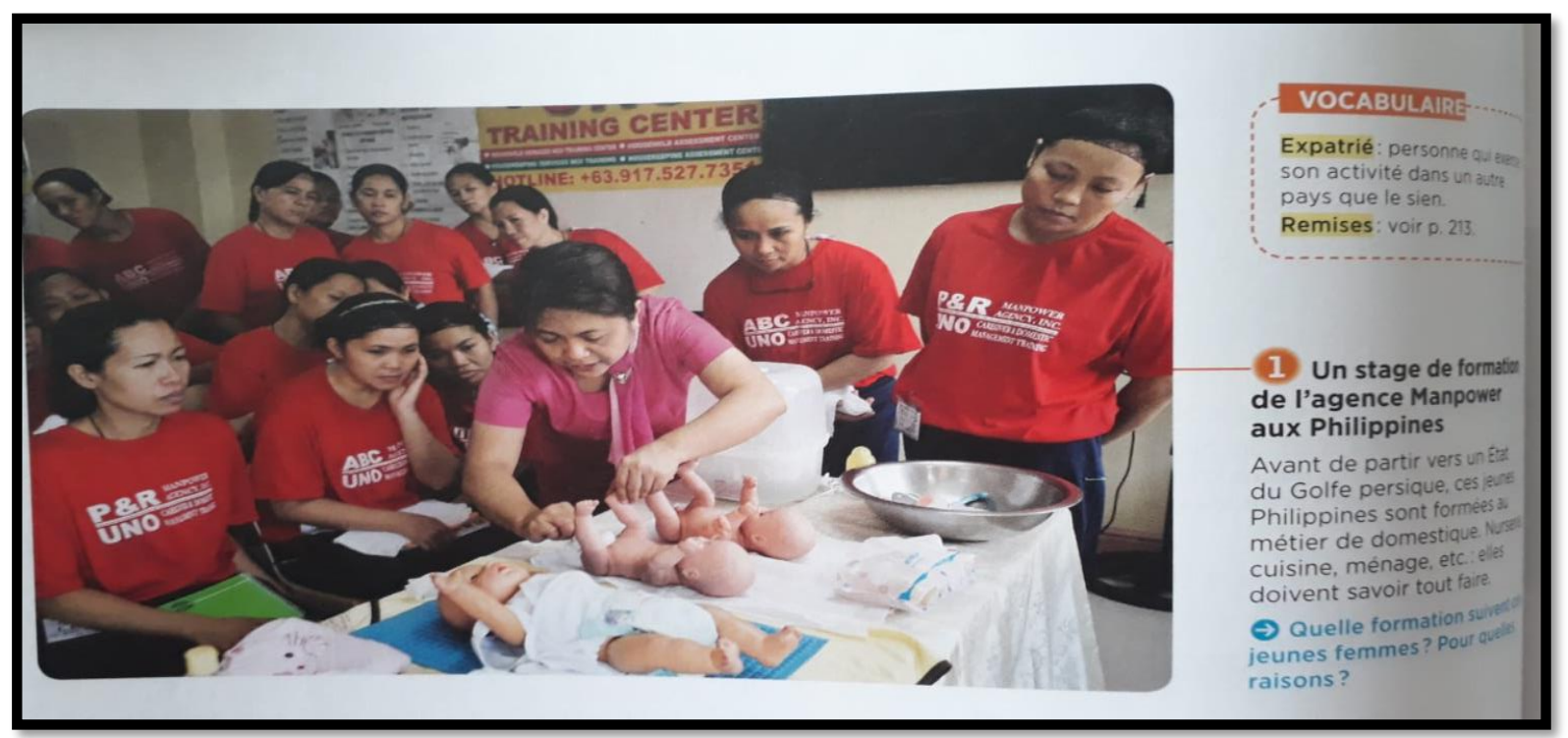

Görsel 1. Hemşire/Ebe

Görsel 1'de çocuk bakımı ile ilgili bir görev resmedilmiştir. Çocuğun giyimi, beslenmesi, genel bakımı gibi çeşitli sorumlulukların ifade edildiği görselde tamamen kadınların olduğu görülmektedir. Bu bağlamda çocuk bakımı ile ilgili görevlerin ifasında yalnızca kadına rol verildiği anlaşılmaktadır. Erkek cinsiyetinin hiç yer almadığı bu görselde keskin bir toplumsal cinsiyet rolünün yansitıldığı görülmektedir. 


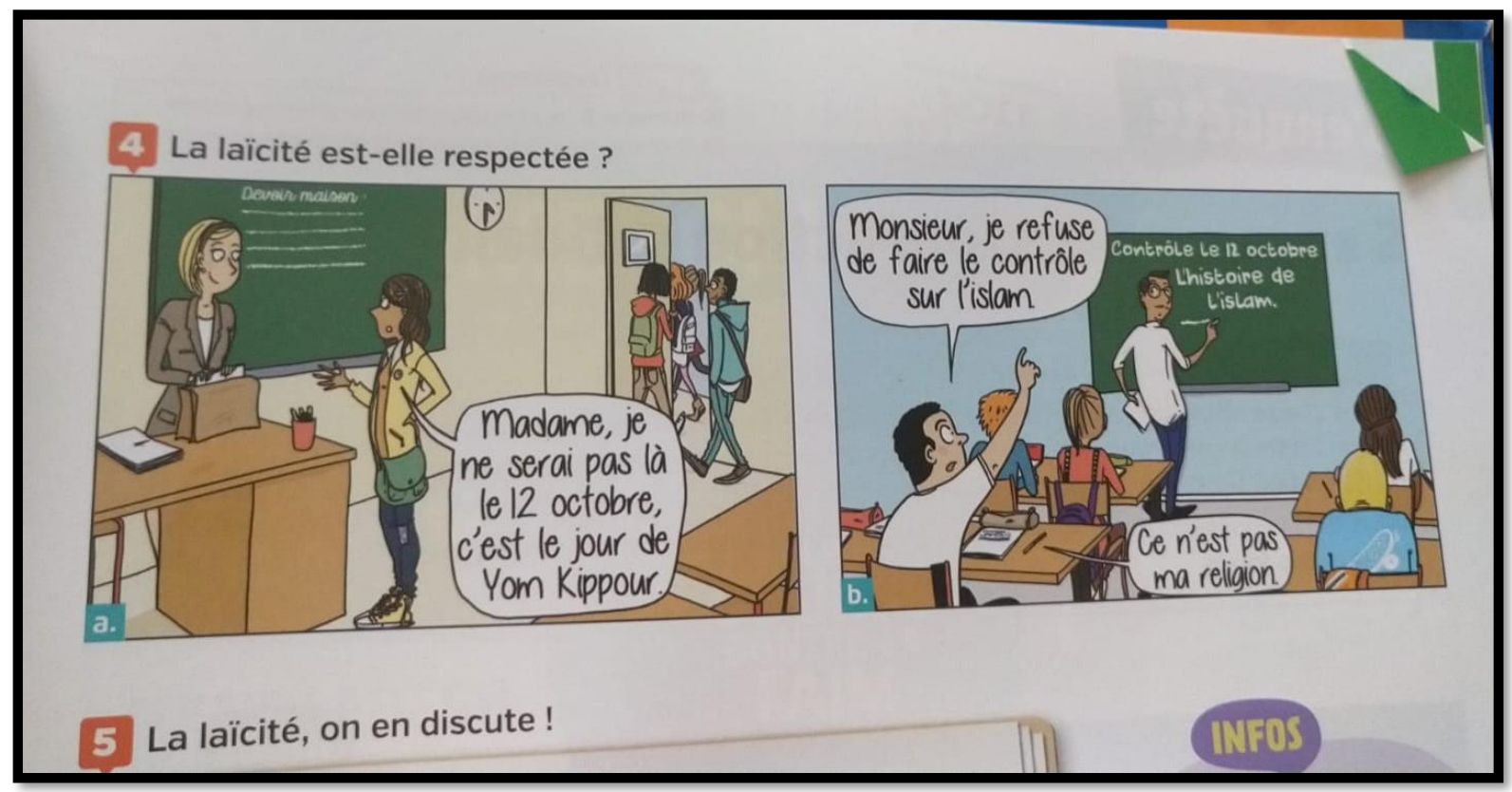

Görsel 2. Öğretmen

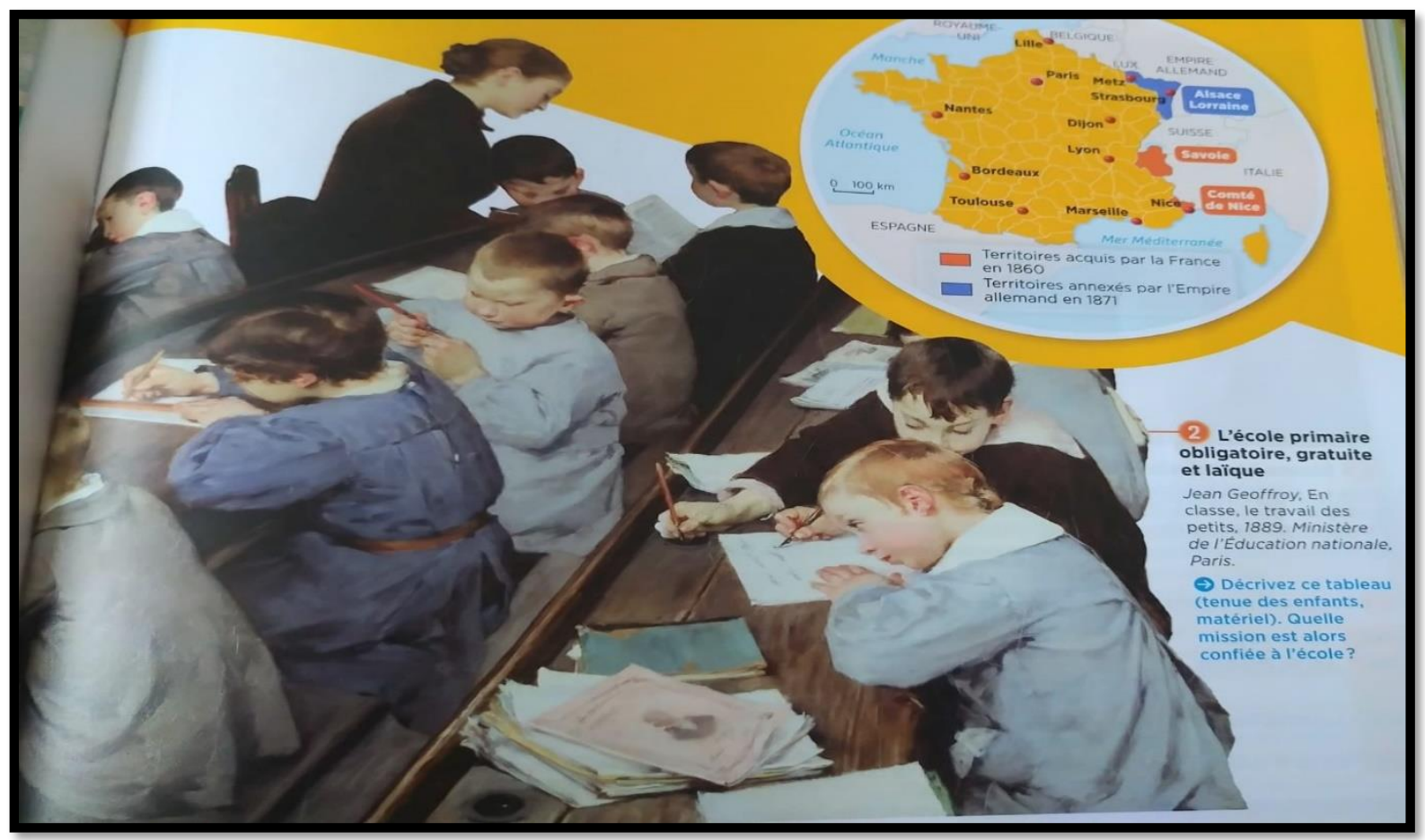

Görsel 3. Öğretmen

Bir sınıf ortamının resmedildiği Görsel 2 ve Görsel 3'te öğretmenlik mesleğinin hem kadın cinsiyetine hem de erkek cinsiyetine atfedildiği görülmektedir. Öte yandan bu görselin ders kitaplarındaki genel dağılımı yansıtmadığı da söylenebilir. Nitekim öğretmenlik mesleğinin ifası ağırlıklı olarak kadın cinsiyetiyle ilişkilendirilirken, erkeklerin öğretmen olarak resmedilme oranı çok daha düşüktür. Sınıf ortamındaki eğitici rol ve sorumlulukların genellikle kadınlar tarafından ifa edildiği anlaşılmaktadır. 


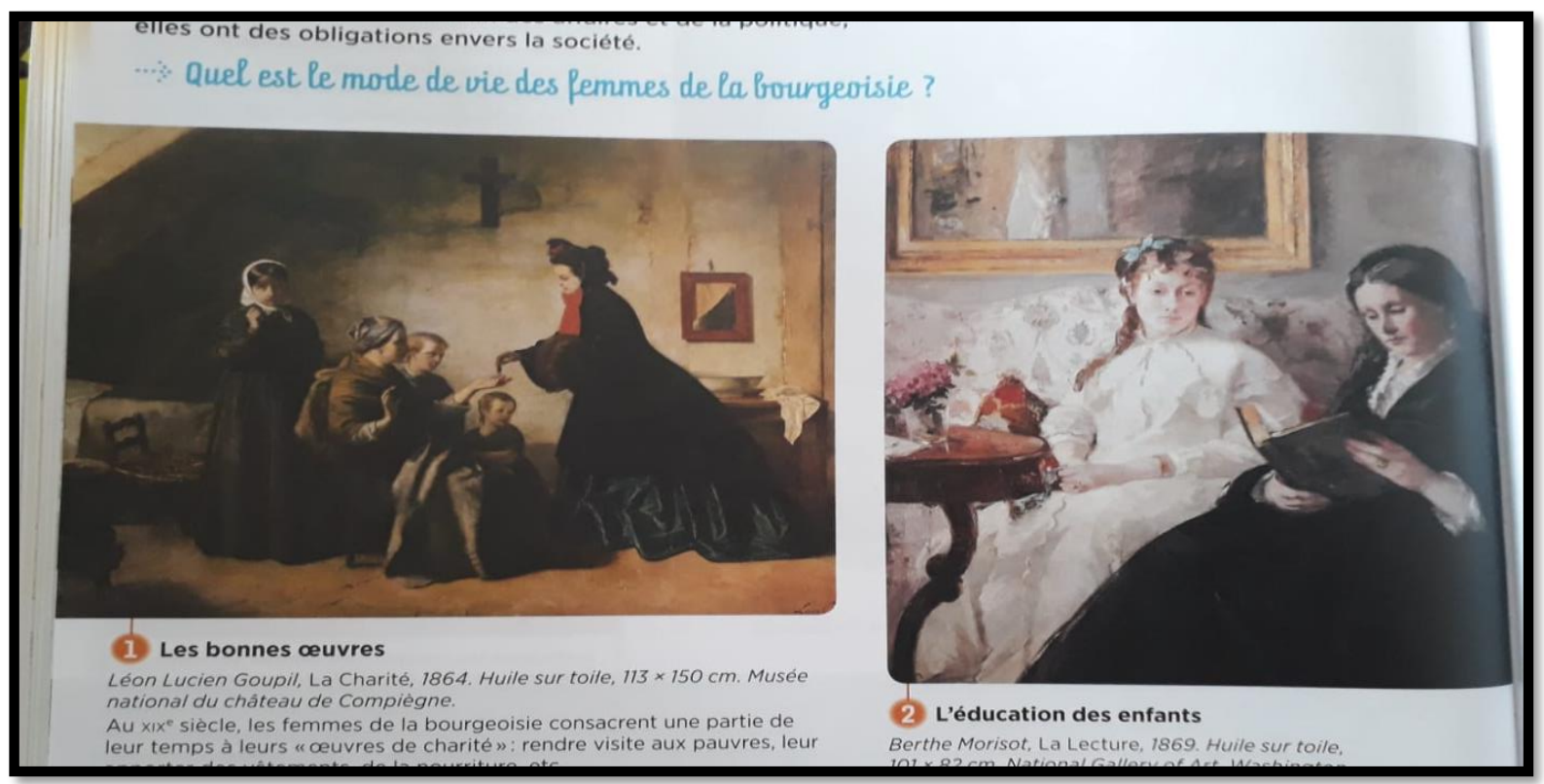

Görsel 4. Ev İşleri

Görsel 4'te ev içi görevler kategorisinde yer alan çocuk bakımı ve ev içindeki çocuk eğitiminden kadınların sorumlu olduğu vurgulanmaktadır. Burada ev içinde sağlıklı ve eğitimli çocuk yetiştirme sorumluluğunun kadınlara biçilmiş olduğu görülmektedir. Görseller incelendiğinde kadınlara atfedilen mesleklerin erkeklere kıyasla daha sınırlı sayıda kaldığı ve ağırlıklı olarak ev içi ortamlara ait olduğu anlaşılmaktadır.

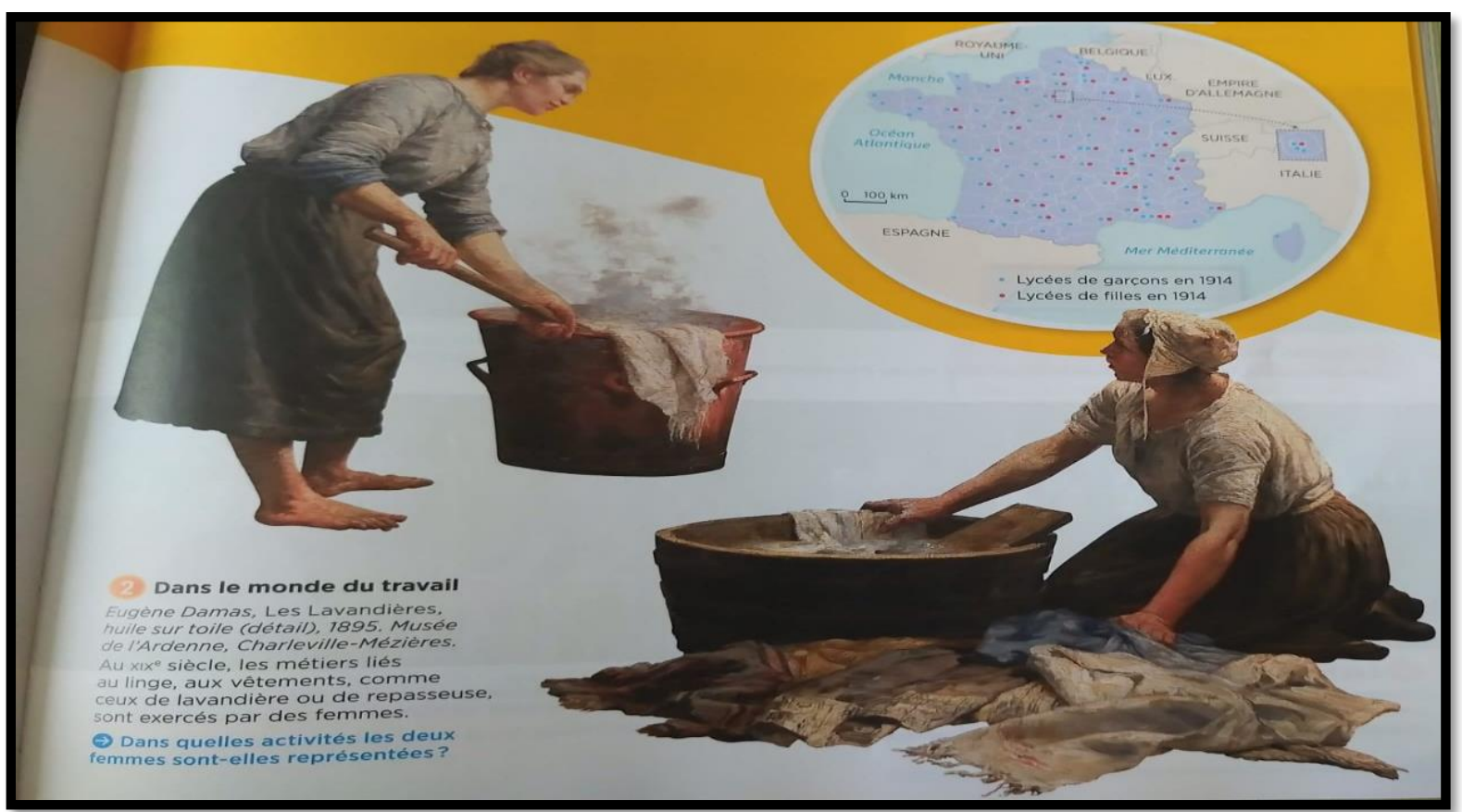

Görsel 5. Ev İşleri 
Görsel 5'te yer alan ve ev içi işlerle meşgul olarak resmedilen kadın figürü evin pek çok ihtiyacını karşılama hususunda önemli sorumluluklara sahiptir. Bu bağlamda toplum tarafından kadına atfedilen bu sorumlulukta erkek cinsiyetinin hiç rol almadığı görülmektedir. Ders kitabında kullanılan bu görsel aracılığıyla toplumda cinsiyet rollerine yönelik bir ayrımcılı̆̆ın var olduğu söylenebilir.

\section{Fransa Ortaokul Tarih ve Coğrafya Ders Kitaplarında Yer Alan Görsellerde Erkek} Cinsiyeti ile İlişkilendirilen Cinsiyet Rolleri ve Mesleki Rollere İlişkin Görseller ve Bulgular

$\mathrm{Bu}$ bölümdeki bazı görsellerde hem kadın hem de erkeklere atfedilen roller bir arada yer almaktadır.

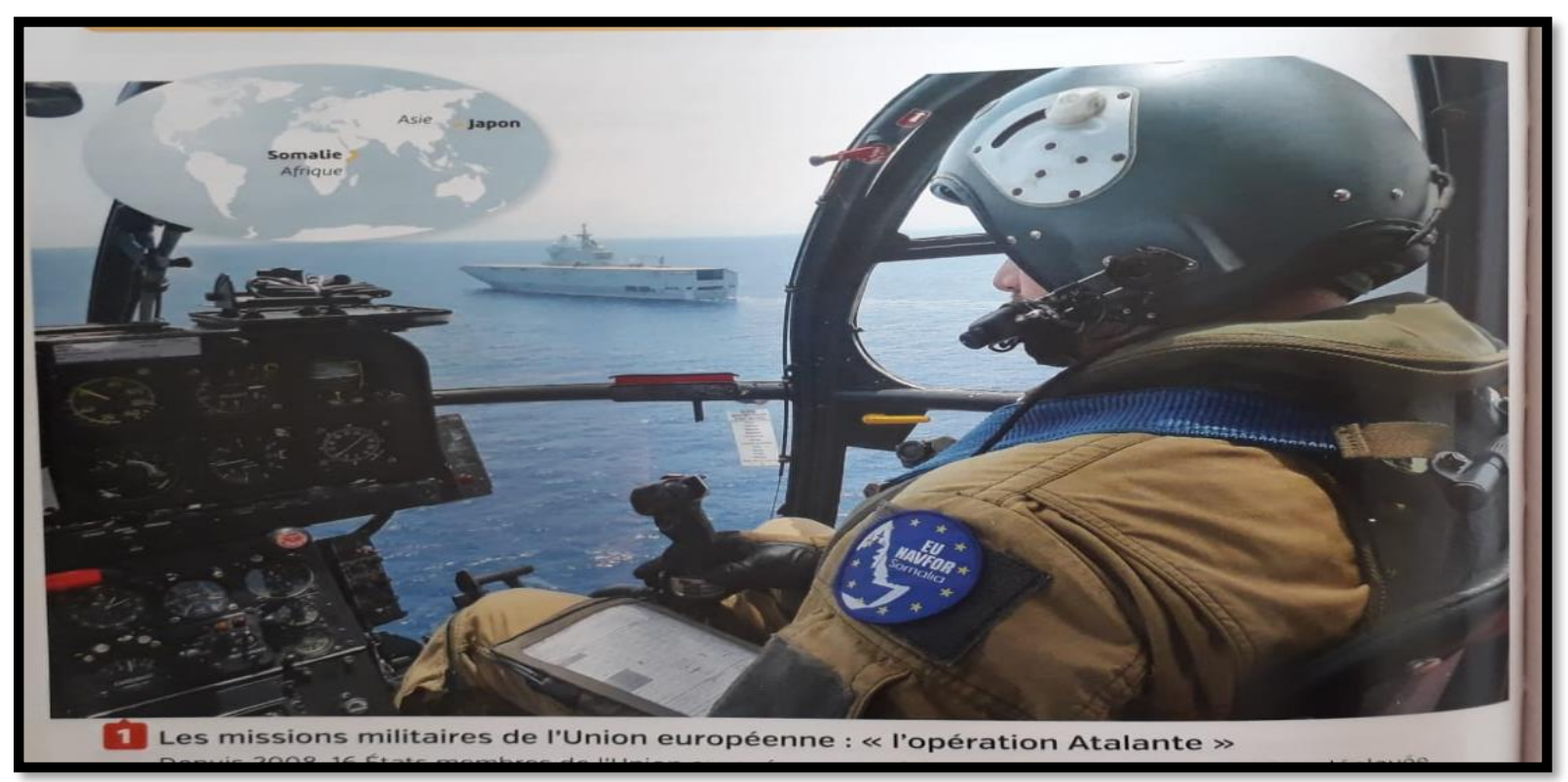

Görsel 6. Asker 


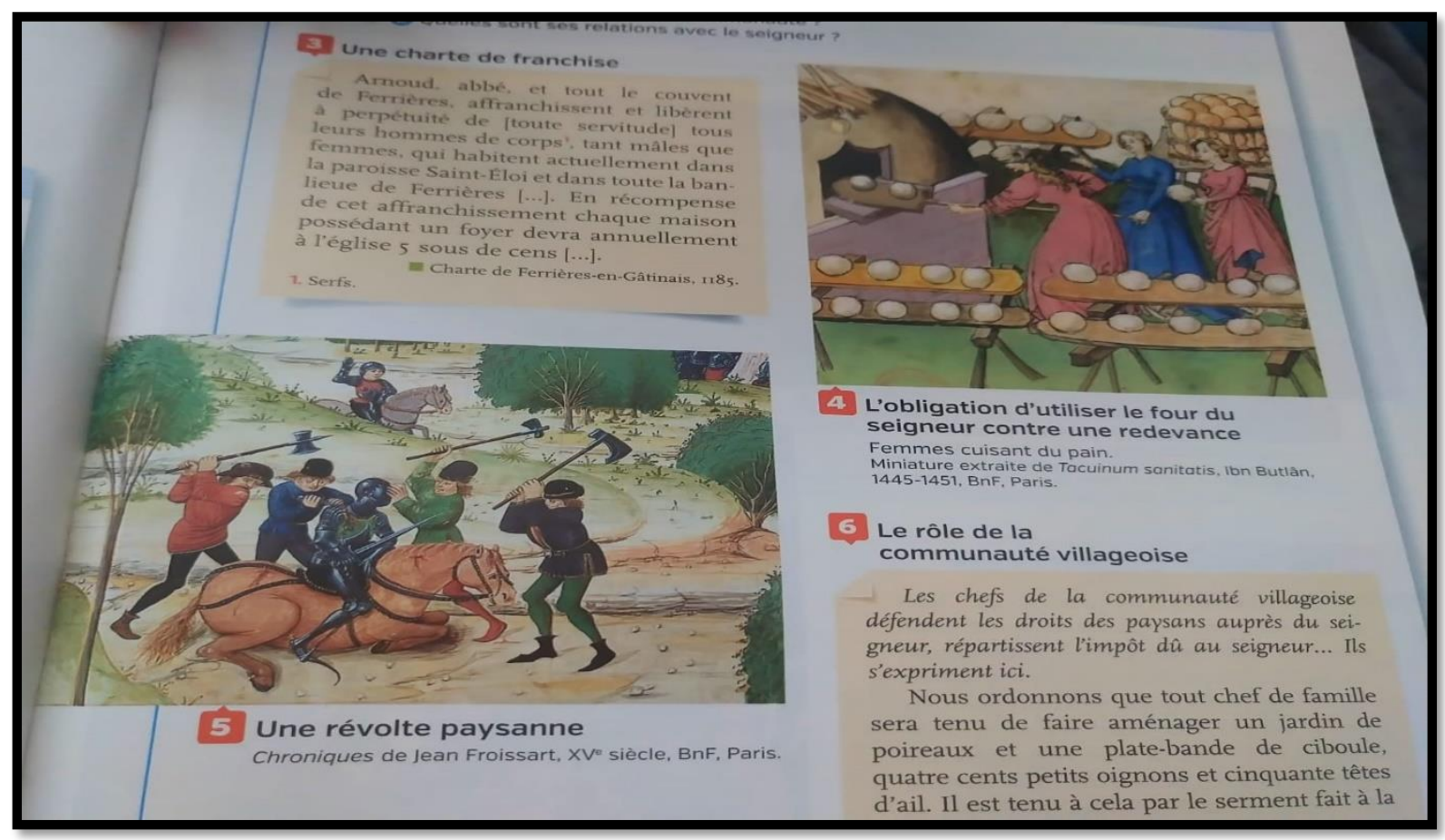

Görsel 7. Asker (Soldaki Görsel) / Ev İşleri (Sağdaki Görsel)

Görsel 6 ve Görsel 7 incelendiğinde askerlik ve pilotluk mesleklerinin erkek cinsiyeti ile daha çok ilişkilendirildiği görülmektedir. Fiziksel güç, otorite isteyen ve ev dişı ortamlarda icra edilen görev ve sorumlulukların daha çok erkek cinsiyete atfedilmektedir. Savaşan erkekler görselinin sağında kadınların hamur yaptıkları resmedilmiştir. Bu durum da ev işlerinin, yemek yapmanın kadınlara ait bir görev olarak vurgulandığını göstermektedir.

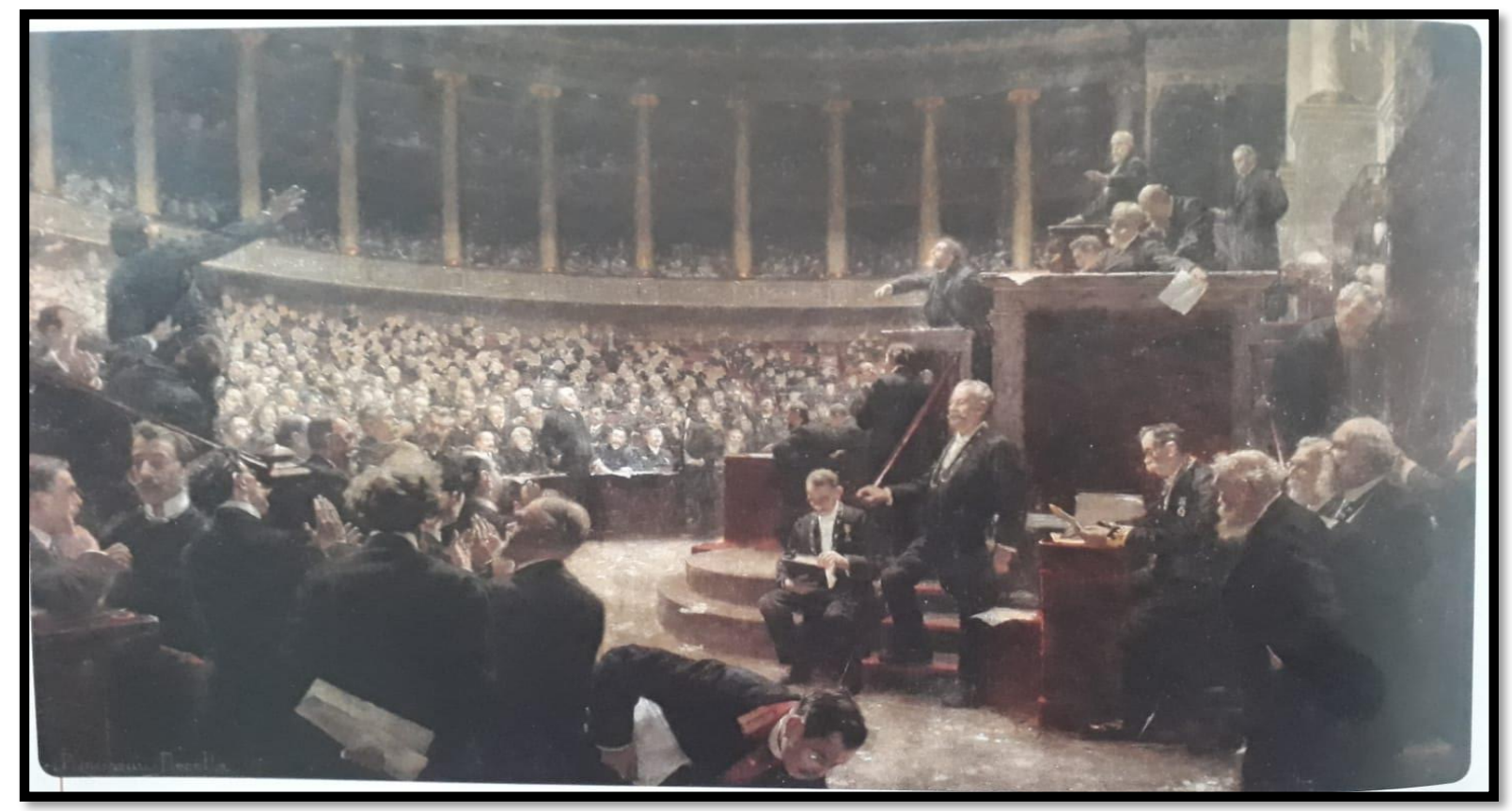

Görsel 8. Politikac1 


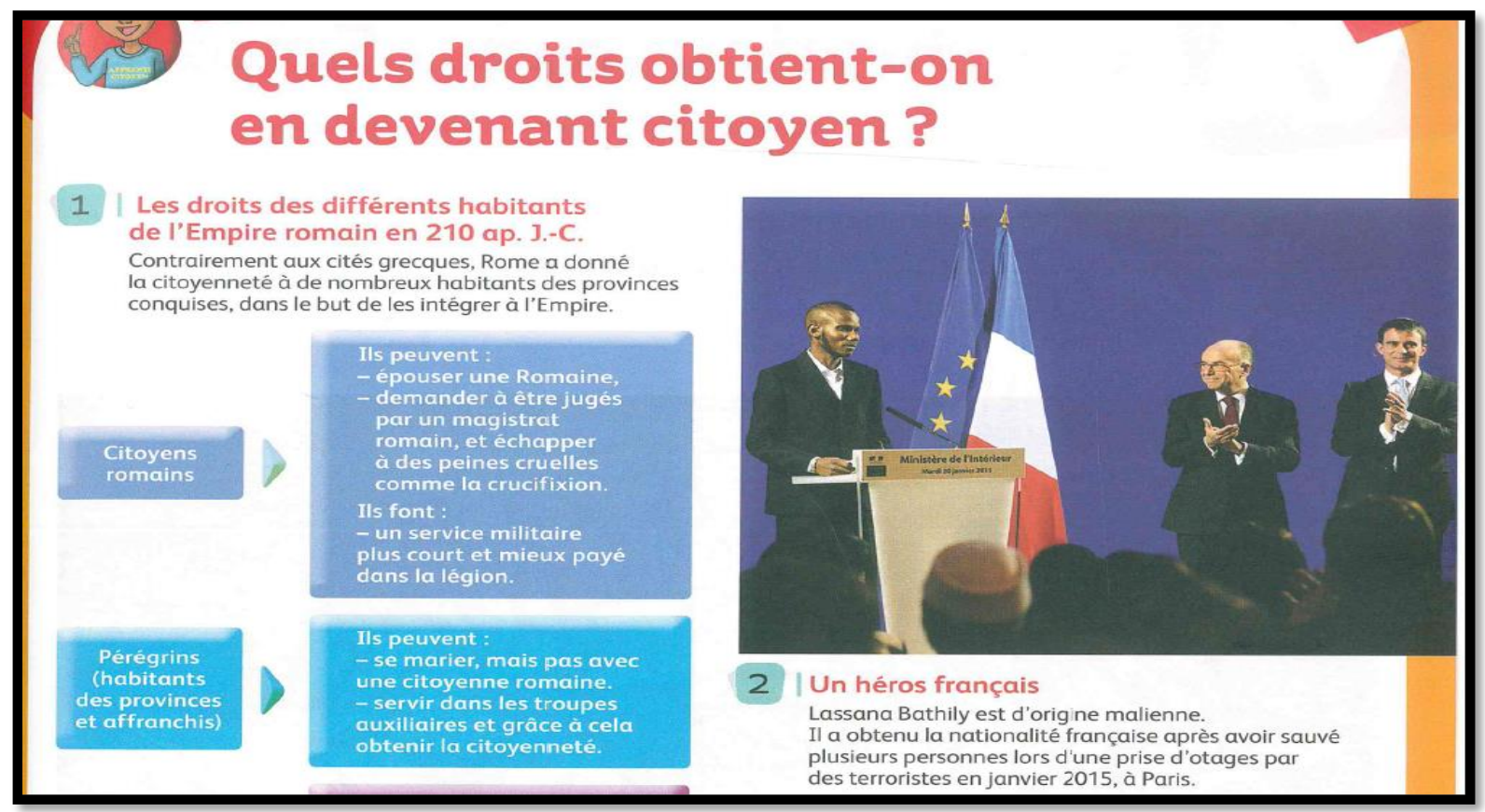

Görsel 9. Politikac1

Devletin ve toplumun yönetilmesin yalnızca erkeklerin söz sahibi olduğunu vurgulayan Görsel 8 ve Görsel 9'da bir meclis resmedilmiştir. Mecliste konuşanların ve dinleyenlerin salt erkeklerin olduğunu göstermektedir. $\mathrm{Bu}$ bağlamda devlet idareciliği, politikacılık gibi mesleklerin erkek cinsiyetine atfedildiği, kadınların bu görev ile ilgili hiçbir sorumlulukla ilişkilendirilmediği anlaşılmaktadır. Ülkeyi doğrudan ilgilendiren devlet idaresi gibi önemli noktalarda yalnızca erkeklerin söz sahibi olduğu mesajını veren bu görsel kadın cinsiyetinin politika ile tasvir edilmediğini göstermektedir

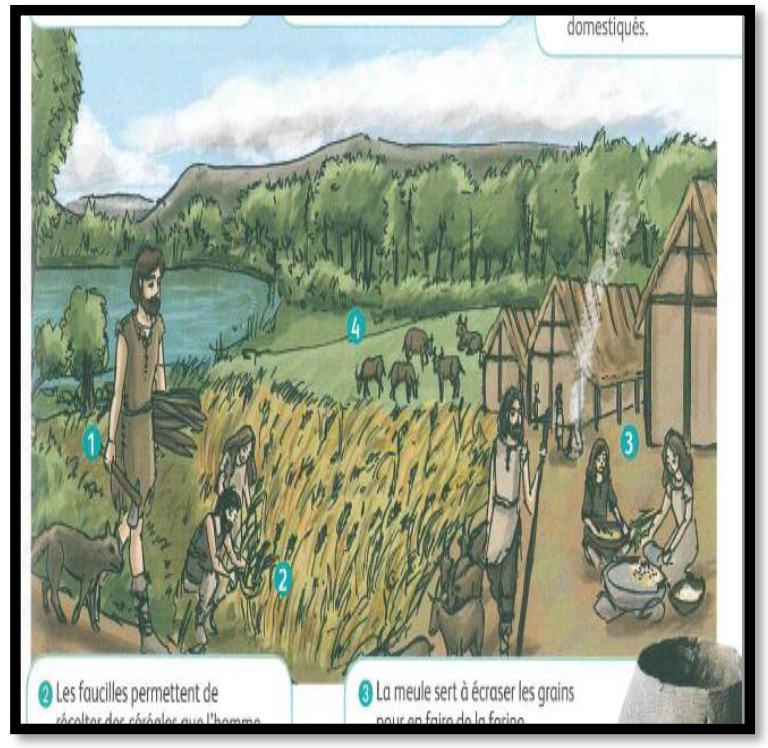

Görsel 10. Çoban

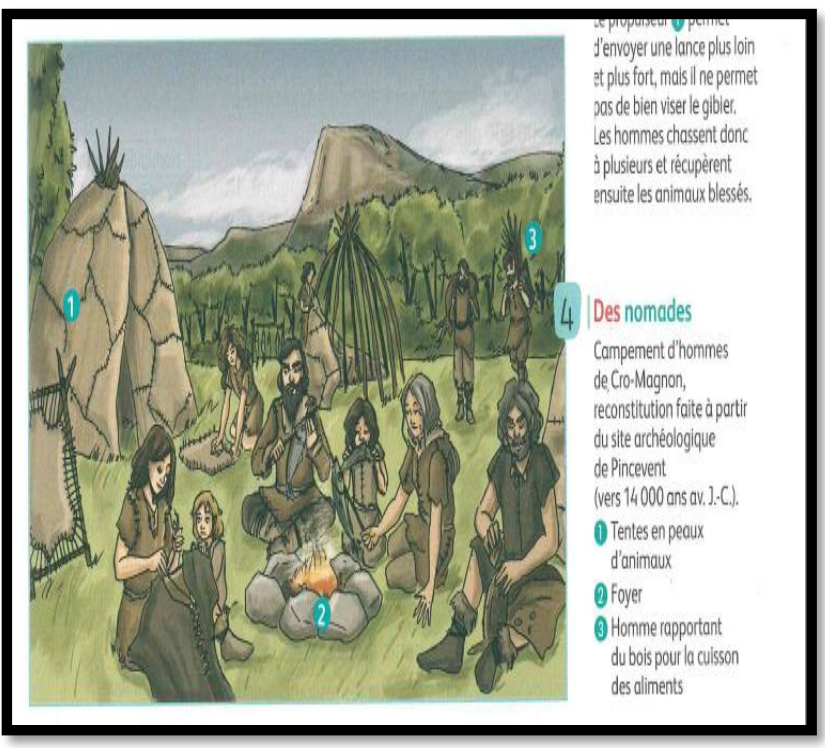

Görsel 11. Ev işleri 
I. $K A R A$,

V. $A K T A S ̧ \&$

T. YAMAN

Fransa Ders Kitaplarında Yer Alan Görsellerin Toplumsal

Cinsiyet Rolleri Bağlamında Incelenmesi: Ortaokul Tarih ve

Coğrafya Dersi Örneği

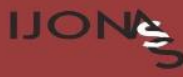

Eski çağlara ait avcı/toplayıcı evreden üretici konuma geçen insanların resmedildiği Görsel 10 ve Görsel 11'de kadın ve erkekler arasında bir iş bölümünün yapıldığı görülmektedir. Hayatta kalma mücadelesinin işlendiği görsellerde kadınların ev içi işlerde görev aldığı, erkeklerin de eve besin temin etme hususunda görev aldığı anlaşılmaktadır.

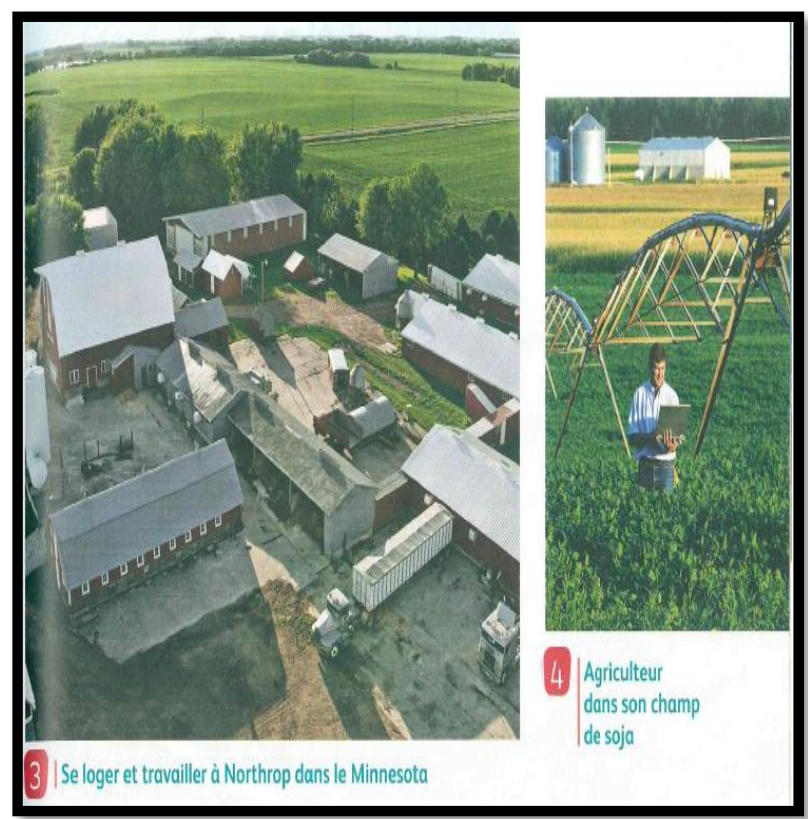

Görsel 12. Mühendis

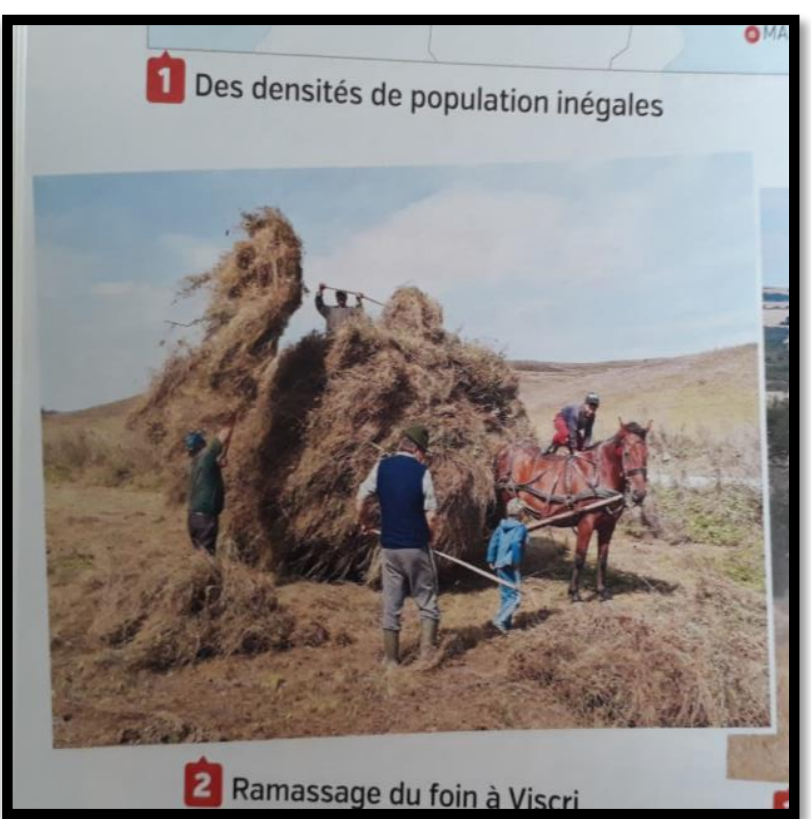

Görsel 13. Çiftçi

\section{J'associe à chaque photographie le type d'agriculture qui lui correspond.}

Choisissez parmi les propositions suivantes: a agriculture productiviste : [b agriculture vivrière. Puis décrivez chacun de ces paysages : activités, outils/type de travail, nombre de personnes, surface cultivée...

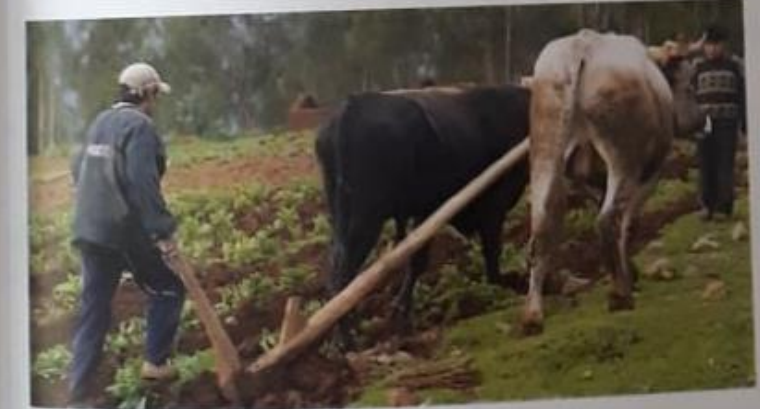

Un agriculteur laboure son champ dans les montagnes de la cordillère des Andes, Pérou, 2013.

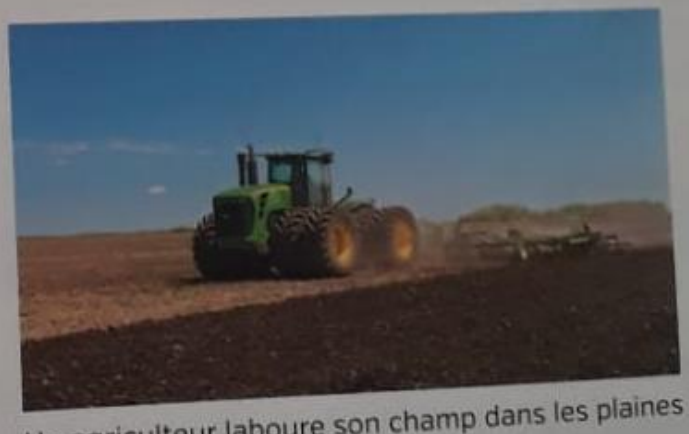

Un agriculteur laboure son champ dans les plaines du Manitoba, Canada, 2014.

Görsel 14. Çiftçi

İncelenen Görsel 12, Görsel 13 ve Görsel 14'te erkek figürünün kullanıldığı görülmekte olup toprak ile uğraşılarda kadın cinsiyetinin hiç yer almadığ görülmektedir. Ev dışı işe yönelik bir eylem olan tarım odaklı mesleklerin erkek tarafından yürütüldüğü anlaşılmaktadır. Sürekli 
bir hareketlilik ve fiziksel güç isteyen bu tür işlerde sorumluluk tamamen erkek cinsiyeti üzerinde gösterilmektedir.

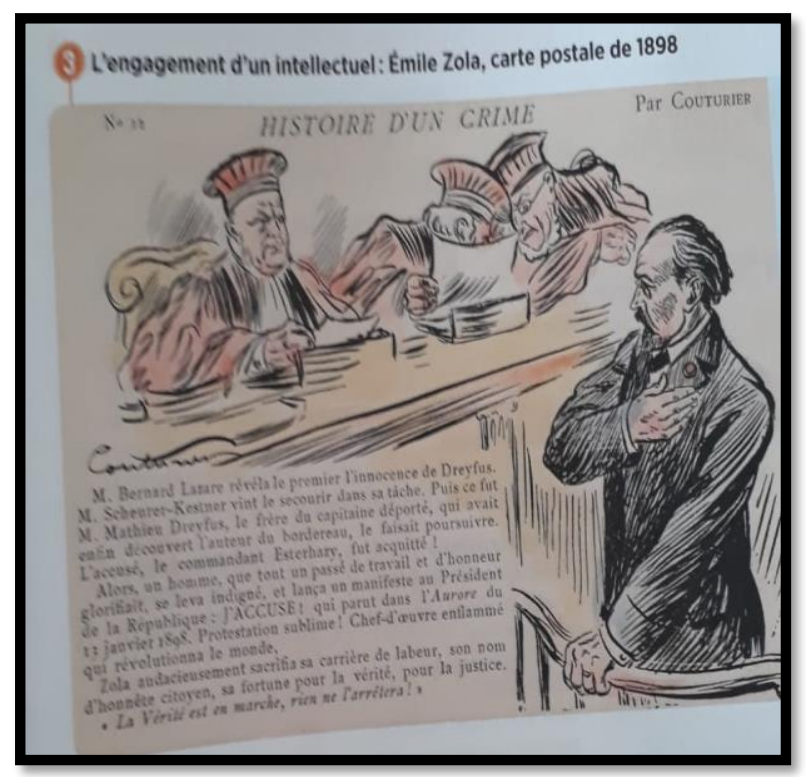

Görsel 15. Hukukçu

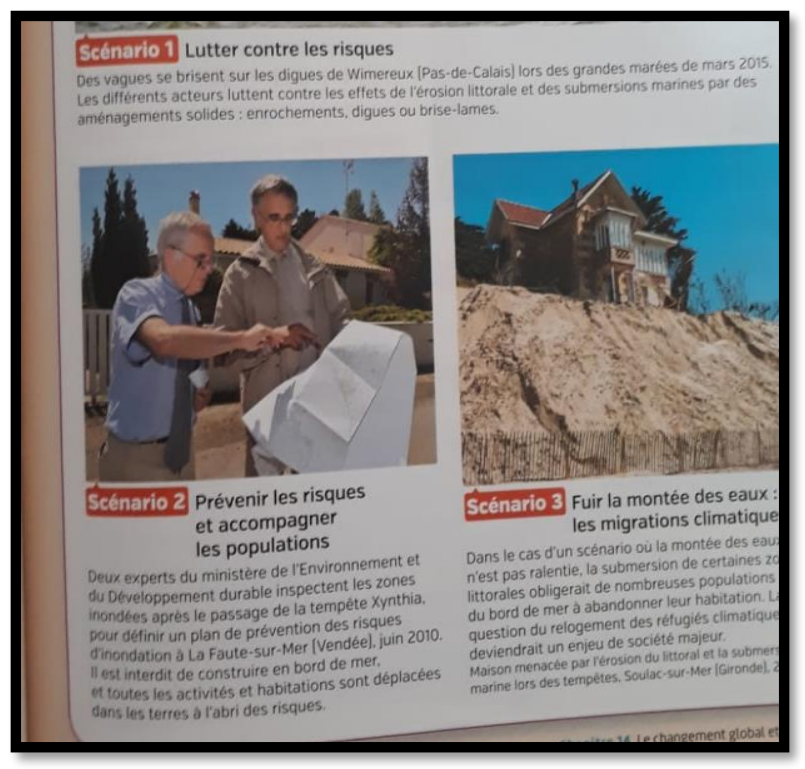

Görsel 16. Mühendis/Müteahhit

Görsel 15'teki hakim/yargıçlar ile Görsel 16'daki mimar/müteahhitlerin erkekler tarafından temsil edildiği anlaşılmaktadır. Diğer görsellerde olduğu gibi bu görsellerde de erkeklerin ev dışı görevlerde sorumluluk aldığ 1 görülmektedir. Söz konusu görsellerde erkeklerin kadınlara nazaran daha çeşitli ve çok sayıda meslekler ile ilişkilendirildiği anlaşılmaktadır.

\section{SONUÇ, TARTIŞMA VE ÖNERİLER}

Bu çalışmada, Fransa ortaokul 5., 6., 7. ve 8. sınıf tarih ve coğrafya ders kitaplarında yer alan görseller toplumsal cinsiyet rollerinin işlenişi ve cinsiyet rollerine bağlı olarak meslek gruplarında farklılaşmanın olup olmadığı bağlamında incelenmiştir. Ders kitaplarında kadınerkek rolleri, anne-baba rolleri ve mesleki rollere ilişkin bulgular elde edilmiştir. Söz konusu bu bulgulardan yola çıkarak araştırmada şu sonuçlara ulaşılmıştır:

Ders kitaplarındaki görsellerde kadın-erkek ve anne-baba rolleri bağlamında; çocuğun giyimi beslenmesi, çocuk bakımı ve ev içi işleri gerektiren görevlerin ifasında yalnızca kadınlara rol verildiği görülmektedir. Erkek cinsiyetinin bu görevlerde yer almadığı ve bu durumun keskin bir toplumsal cinsiyet rolü sergilediği sonucuna ulaşılmıştır. Benzer bir sonuca Sarıtaş ve Şahin (2018)'in Türkiye kaynaklı çalışmasında da rastlanmaktadır. Söz konusu çalışmada kadınların daha çok çocuk bakımı ve ev içi sorumluluklar üstlendiği bulgusuna ulaşılmıştır. Kırbaşoğlu-Kılıç ve Eyüp (2011) tarafından Türkiye'de ilköğretim seviyesinde okutulmakta olan Türkçe ders kitaplarına ilişkin yapılan araştırmada çocukla ilgilenmek ve ev içi işlerle meşgul olmak kadınlara atfedilen temel roller arasında yer almaktadır. Güney (2016)'in Türkiye 6. sınıf Türkçe ders kitaplarına yönelik yapmış olduğu çalışmada da kadın karakterlerin aile içinde en sık yaptığı eylemler arasında çocukla ilgilenmek ve ev işleri yapma yer almaktadır. Barton ve Sakwa (2012) Uganda ders kitaplarına ilişkin yaptıkları araştırmalarında kadınların ev içi rollerde temsil edildiği bulgusuna ulaşmıştır. Bu sonuçların aksine, Başaran (2019)'ın araştırmasında durum farklılık göstermektedir. Söz konusu 
çalışmada ders kitaplarında toplumsal cinsiyet açısından daha olumlu sonuçlara ulaşılmıştır. İlgili araştırmada kız çocuklarının daha çok ev işleriyle uğraşan değil kitap okuyan, sosyal etkinlikler yapan konumunda tasvir edildiği görülmektedir. Erkek çocuklarının ise evde annesine yardım etme ve temizlik yapma gibi görevlerle ilişkilendirildikleri bulgusu yer almaktadır. Buna paralel bir sonuç da Çebi-Kozallık ve Kargı (2019)'nın çalışmalarında yer almaktadır. Araştırmacılar Türkçe ve Almanca ders kitaplarını incelemiş ve Almanca ders kitaplarında erkeğin ve erkek çocuklarının ev işlerinde de sorumluluk aldığı sonucuna ulaşmıştır. $\mathrm{Bu}$ sonuçlar, ders kitaplarındaki toplumsal cinsiyet rollerinin ayrımını en aza indirme konusunda olumlu bir gelişme yaşandığını göstermektedir.

Ders kitaplarındaki görsellerde kadın-erkek ve anne-baba rolleri bağlamında; kadın ve erkek arasında bir iş bölümünün yapıldığı görülmektedir. Avcı/toplayıcı evreden üretici konuma geçen insanların ve hayatta kalma mücadelesinin tasvir edildiği görsellerde; kadınların ev içi işlerde görev aldığ 1 , erkeklerin ise eve besin temin etme hususunda görev aldığ 1 görülmektedir. Kırbaşoğlu-Kılıç ve Eyüp (2011)'ün araştırmalarında da kadınlar tamamen ev içi rollerde gösterilirken, erkekler evin tamir işleriyle ilgilenen ve evin maddi geçimini sağlarken gösterilmektedir. Benzer bir sonuç Güney (2016)'in çalışmasında da görülmektedir. Söz konusu çalışmada kadınların yemek yapma ve ev işleriyle ilgilenme gibi görevlerle tasvir edildiği, erkeklerin ise daha çok evi yönetme ve idare etme gibi görevlerle tasvir edildiği bulgusu yer almaktadır. Bu durum anne ve baba rolleri bağlamında bir farklılaşmanın olduğunu göstermektedir.

Ders kitaplarındaki görsellerde mesleki roller bağlamında; bazı mesleklerin, öğretmenlik mesleğinde, hem kadın cinsiyetine hem de erkek cinsiyetine atfedildiği görülmektedir. Ancak bu görsellerin ders kitaplarındaki genel dağılımı yansıtmadığı söylenebilir. Çünkü öğretmenlik mesleğinin ifası ağırlıklı olarak kadın cinsiyetiyle ilişkilendirilirken, erkeklerin öğretmen olarak resmedilme oranı çok daha düşüktür. Bu durum sınıf ortamındaki eğitici rol ve sorumlulukların genellikle kadınlar tarafından yerine getirildiği sonucunu doğurmaktadır. Tezer-Asan (2010)'ın araştırmasında da kadınlara daha çok öğretmenlik gibi mesleklerin önerildiği bulgusu yer almaktadır. Satılmış (2019) tarafından yapılan çalışmada kadın cinsiyetine öğretmenlik mesleğinin atfedildiği görülmektedir. Söz konusu araştırma bulguları ile bu çalışmanın bulguları paralellik göstermektedir.

Ders kitaplarındaki görsellerde mesleki roller bağlamında; bazı mesleklerin, askerlik ve pilotluk mesleğinde olduğu gibi, erkek cinsiyeti ile daha çok ilişkilendirildiği görülmektedir. Fiziksel güç, otorite isteyen ve ev dışı ortamlardaki bu tür işlerin erkekler tarafından daha iyi şekilde yapılacağına dair bir algı oluşturulmuştur. Bunun yanı sıra aynı görsellerde yer alan kadınların hamur yaptıkları görülmekte olup bu durum ev işleri ve yemek yapmanın kadınlara ait bir görev olduğu izlenimi yaratmaktadır. Kadın ve erkek cinsiyeti bağlamında yapılan bu tür ayrımların keskin bir toplumsal cinsiyet rolü oluşturduğu sonucuna ulaşılmıştır. Sarıtaş ve Şahin (2018)'in Türkiye' deki hayat bilgisi ders kitaplarına ilişkin yapmış olduğu araştırmada, mesleki roller bakımından kadın ve erkek rollerinin farklılaştığı; bu bağlamda erkeklere daha çok güç ve otorite gerektiren meslekler atfedildiği, kadınlara ise evle ilgili ve çocuk bakımına yakın mesleklerin atfedildiği görülmektedir. Tezer-Asan (2010)'ın Türkiye ilköğretim okullarında okutulmakta olan ders kitaplarını incelediği çalışmasında da erkeklerin tamircilik gibi güç gerektiren mesleklerle ilişkilendirildiği, kadınların ise ev hanımlığı gibi mesleklerle ilişkilendirildiği bulgusu yer almaktadır. Bu sonuçlar kadın ve erkek cinsiyetine atfedilen mesleki roller bağlamında önemli ayrılıkların olduğunu göstermektedir. 
Ders kitaplarındaki görsellerde mesleki roller bağlamında; bazı mesleklerin, devlet idareciliği ve politikacılık gibi, sadece erkek cinsiyetine atfedildiği öte yandan kadınların bu mesleklerle hiçbir şekilde ilişkilendirilmediği anlaşılmaktadır. Ülkeyi doğrudan ilgilendiren devlet idaresi gibi önemli noktalarda yalnızca erkeklerin söz sahibi olduğu mesajını veren bazı görseller, kadın cinsiyetinin politika ile tasvir edilmediğini göstermektedir. Özdemir ve Balc1Karabaoğa (2019) tarafından yapılan çalışmada da erkeklerin daha çok profesyonel meslekler içerisinde yer aldığ 1 görülmektedir. Devlet idareciliği ve politikacılık mesleklerinde olduğu gibi ev dışı işe yönelik bir eylem olan toprak ile ilgili uğraşılarda başka bir ifadeyle tarım odaklı mesleklerde kadın cinsiyetinin hiç yer almadığ 1 ve bu tür faaliyetlerin erkekler tarafından yürütüldüğü görülmektedir. Sürekli bir hareketlilik ve fiziksel güç isteyen bu tür işlerde sorumluluk tamamen erkek cinsiyeti üzerinde gösterilmektedir. Táboas-Pais \& ReyCao (2012) çalışmalarında İspanya'da okutulan ders kitaplarını incelemiş ve çalışmanın sonucunda erkeklerin dış mekanlara bağlı işlerle ilişkilendirildikleri bulgusuna ulaşmışlardır. Sarıtaş ve Şahin (2018)'in araştırmasında da erkeklere genellikle ev dışı sorumlulukların yüklendiği görülmekte olup bu sonucu Kırbaşoğlu-Kılıç ve Eyüp (2011) tarafından yapılan araştırma bulguları da desteklemektedir. Söz konusu araştırmada erkekler dişarıda çalışan kişiler olarak tasvir edilmektedir. Kadın ve erkek cinsiyeti bağlamında yapılan bu tür ayrımların toplumsal cinsiyet rolü algısı yarattığı sonucuna ulaşılmaktadır.

Ders kitaplarındaki görsellerde mesleki roller bağlamında; bazı mesleklerin, mimar/müteahhit, hakim ve yargıç meslekleri gibi, erkekler tarafından temsil edildiği ancak bu mesleklerin tasvirinde kadın cinsiyetine yer verilmediği görülmektedir. Söz konusu görseller aracılığıyla erkeklerin kadınlara nazaran daha çeşitli ve çok sayıda meslekler ile ilişkilendirildiği sonucuna ulaşılmaktadır. Ders kitaplarında toplumsal cinsiyet rollerinin incelendiği araştırmalar (Kırbaşoğlu-Kılıç \& Eyüp, 2011; Yıldız, 2013; Güney, 2016; Sarıtaş \& Şahin, 2018; Özdemir \& Balc1-Karabaoğa, 2019) sonucunda da mesleki rollerde kadınlara oldukça sınırlı sayıda yer verildiği, erkeklerin ise birbirinden farklı meslek çeşidiyle temsil edildiği bulgusu yer almaktadır. Bu durum mesleki roller bakımından kadın ve erkek cinsiyetleri arasında belirgin bir ayrımcılığın varlığına işaret etmektedir.

Araştırmada Fransa ortaokul tarih ve coğrafya ders kitaplarında yer alan görsellerin kadınerkek ve anne-baba rolleri bağlamında incelenmesi sonucunda; kadınların daha çok ev içi işlerle meşgul olduğu, çocuk temizliği, çocuk bakımı ve çocuk eğitimi gibi işlerle uğraştığı yine başka bir ev içi faaliyeti olan ev temizliğinin yapılması ve yiyecek-içecek gibi ihtiyaçların hazırlanması görevlerini üstlendiği görülmektedir. Erkeklerin ise tarım ve toprak gibi işlerle uğraşarak temel besin kaynaklarını karşıladığı görülmektedir. Ders kitaplarındaki görsellerin mesleki roller bağlamında incelenmesi sonucunda ise; kadınların daha çok ev hanımlığ1 ve öğretmenlik gibi mesleklerle ilişkilendirildiği; erkeklerin ise asker, pilot, politikacı, çiftçi, mimar/müteahhit, hakim/yargıç gibi mesleki roller ile ilişkilendirildiği görülmektedir. Bu bağlamda kadınlara atfedilen mesleklerin erkeklere atfedilen mesleklere kıyasla daha sınırlı olduğu görülmektedir. Kısacası ders kitaplarındaki görsellerde kadınerkek rolleri bağlamında önemli farklılıkların olduğu ve bu durumun anne-baba rolleri ve mesleki roller üzerinde de önemli bir etki yarattı̆̆ görülmektedir.

Ders kitaplarında toplumsal cinsiyet rollerinin incelendiği hem ulusal hem de uluslararası alanda yapılan araştırma sonuçları okullarda okutulmakta olan ders kitaplarında toplumdaki anne-baba rollerinde, mesleki rollerde ve daha genel anlamda kadın-erkek rollerinde ciddi bir ayrımcılığın olduğunu göstermektedir. Oysaki 21. yüzyıl şartlarında yeni yetişen nesillerin kendini geliştiren, çağdaş, insan hak ve özgürlüklerine saygılı bireyler olarak yetişmeleri arzu 
I. $K A R A$,

V. $A K T A S ̧ \&$

T. YAMAN

Fransa Ders Kitaplarında Yer Alan Görsellerin Toplumsal Cinsiyet Rolleri Bağlamında Incelenmesi: Ortaokul Tarih ve

Coğrafya Dersi Örneği

edilmektedir. Ancak yukarıda bahsi geçen araştırma sonuçlarında da yer aldığı gibi, ders kitaplarında var olan cinsiyet ayrımcılığına ilişkin durum ile gerçekleştirilmesi arzu edilen durum arasında büyük bir tutarsızlık bulunmaktadır. Söz konusu bu tutarsızlığın yok edilmesi için ülkeler okullarda okutulmakta olan ders kitaplarını günümüz koşul ve beklentilerine uygun olacak şekilde düzenlemelidir. Bu bağlamda çalışmanın sonuçları 1şığında aşağıdaki önerilerde bulunulabilir:

- Bu çalışma sadece tarih ve coğrafya ders kitaplarıyla sınırlı olup diğer disiplinlere ait ders kitaplarına ilişkin çalışmalar da yürütülebilir.

- Söz konusu ders kitaplarını hazırlayan komisyonlar toplumsal cinsiyet rolleri üzerine yapılan araştırmaları inceleyerek gerekli iyileştirmeleri yapabilir.

\section{KAYNAKÇA}

Akın, A. \& Demirel, S. (2003). Toplumsal cinsiyet kavramı ve sağlı̆̆a etkileri. C. Ü. Tip Fakültesi Dergisi, 25(4), 73-82.

Barton A. \& Sakwa L. N. (2012) The representation of gender in English textbooks in Uganda. Pedagogy, Culture \& Society, 20(2), 173-190.

Başaran, M. (2019). Sosyal bilgiler öğretim programı ve ders kitaplarında toplumsal cinsiyet eşitliği eğitimi. [Yayımlanmamış yüksek lisans tezi]. Necmettin Erbakan Üniversitesi Eğitim Bilimleri Enstitüsü.

Blumberg, R. L. (2008). The invisible obstacle to educational equality: Gender bias in textbooks. Prospects, 38, $345-361$.

Cherry, A. L. (2005). Examiningghbal social welfare issues. ThomsonBrooks/Cole.

Collectif (2016). Histoire géographie 3e cycle 4- livre de l'èleve. Nathan Maison d'èdition.

Collectif (2016). Histoire géographie 4e cycle 4- livre de l'èleve. Nathan Maison d'èdition.

Collectif (2016). Histoire géographie 5e cycle 4- livre de l'èleve. Nathan Maison d'èdition.

Collectif (2016). Histoire géographie 6e cycle 3- livre de l'èleve. Nathan Maison d'èdition.

Çebi-Kozallık, R. H. \& Kargı, B. (2019). Türkçe ve Almanca ilköğretim ana dil ders kitaplarında toplumsal cinsiyete bir bakış. OPUS Uluslararası Toplum Araştırmaları Dergisi, 13(19), 50-74.

Dökmen, Y. Z. (2004). Toplumsal cinsiyet sosyal psikolojik açılamalar. Sistem Yayıncılık.

Dökmen, Z. Y. (2010). Toplumsal cinsiyet sosyal psikolojik açıklamalar. Sistem Yayıncılık.

Evans, M. A. \& Saint-Aubin, J. (2005). What children are looking at during shared storybook reading. Psychological Science, 16, 913-920.

Fan, L. \& Kaeley, G. (2000). The influence of textbooks on teaching strategies. Mid-Western Educational Researcher, 13(4), 2-9.

Güney, N. (2016). 6. sınıf Türkçe ders kitaplarında toplumsal cinsiyet incelemesi. Turkish Studies, 11(3), 2291248.

Helvacıŏlu-Gümüşoğlu, F. (1994). 1928'den 1994'e ders kitaplarında cinsiyetçilik [Yayımlanmamış doktora tezi]. İstanbul Üniversitesi Sosyal Bilimler Enstitüsü.

Kırbaşoğlu-Kılıç, L. \& Eyüp, B. (2011). İlköğretim Türkçe ders kitaplarında ortaya çıkan toplumsal cinsiyet rolleri üzerine bir inceleme. ODTÜ Sosyal Bilimler Enstitüsü Sosyal Bilimler Araştırmaları Dergisi, 3 (2), ss. 129-148.

Maher, F. A. \& Ward, J. V. (2008). Gender and teaching. Lawrence Erlbaum Associates, Inc., Publishers.

Marshall, G. (1999). Sosyoloji sözlüğ̈̈̈ (Çev. O. Akınhay). Bilim ve Sanat Yayınları.

Merriam, S. B. (2013). Qualitative research a guide to design and Implementation (Çev. Ed. S. Turan). Nobel Yayıncilik. 
Miles, M. B. \& Huberman, A. M. (1994). An expanded sourcebook: Qualitative data analysis (2th edition). SAGE Publications.

Özdemir, E., \& Karaboğa-Balcı A. (2019). Ortaokul matematik ders kitaplarında toplumsal cinsiyet. Mersin Üniversitesi Eğitim Fakültesi Dergisi, 15(3), 760-781.

Sanford, L. \& Donovan, M. E. (1999). Kadınlar ve benlik saygısı (Çev: S. Kunt). HYB.

Sarıtaş, E. \& Şahin, Ü. (2018). Hayat bilgisi ders kitaplarında toplumsal cinsiyet rolleri üzerine bir inceleme. Mehmet Akif Ersoy Üniversitesi Ĕ̆itim Fakültesi Dergisi, 48, 463-477.

Satilmiş, S. (2019). 5. Sınıf Türkçe ders kitabının toplumsal cinsiyet açısından incelenmesi. Eskişehir Osmangazi Üniversitesi Sosyal Bilimler Dergisi, 20, 1249-1262.

Scott, W. J. (2007). Toplumsal cinsiyet: Faydalı bir tarihsel analiz (Çev. A. T. Kılıç). Agora Yayınları.

Stoller, R. J. (1968). Sex and gender, the development of masculanity and family. H. Karnac Books.

Şeker, M. \& Dinçer, A. (2014). An analysis of gender stereotyping in english teaching course books. Çukurova University Faculty of Education Journal, 43(1), 90-98.

Şirvanlı Özen, D. (1992). Annenin çalışma durumu ve ebeveynin benimsediği cinsiyet rolü değişkenlerinin çocuğun cinsiyet özelliklerine ilişkin kalıpyargılarının gelişimine etkisi [Yayımlanmamış yüksek lisans tezi]. Hacettepe Üniversitesi Sosyal Bilimler Enstitüsü.

Táboas-Pais, M. I. \& Rey-Cao, A. (2012). Gender differences in physical education textbooks in Spain: a content analysis of photographs. Sex Roles, 67, 389-402. https://doi.org/10.1007/s11199-012-0174-y.

Tezer-Asan, H. (2010). Ders kitaplarında cinsiyetçilik ve öğretmenlerin cinsiyetçilik algılarının saptanması. Fe Dergi, 2(2), 65-74.

Wortham, S.C. (2002). Early childhood curriculum: developmental bases for learning and teaching. 3rd Ed. Pearson Education.

Yıldırım, A. \& Şimşek, H. (2013). Sosyal bilimlerde nitel araştırma yöntemleri. (9. Baskı). Seçkin Yayıncılık.

Yıldız, M. (2013). İlkokul ve ortaokul din kültürü ve ahlak bilgisi kitapları görsellerinin toplumsal cinsiyet açısından incelenmesi. Dini Araştırmalar Dergisi, 16(42), 143-165. 


\section{EXTENDED ABSTRACT}

\section{The Study of Visuals in French Coursebooks in The Context of Social Gender Roles: The Sample of History and Geography Subjects in the Middle School}

\section{Introduction}

Humans need to socialize as they are social creatures. To maintain that, it acts in the line of the expectations of the society in which it lives. An individual is approved when s/he acts in accordance with the social norms and his/her those actions are reinforced. When s/he does not act in accordance with the social norms, s/he gets alienated by the society and this situation is not welcomed. Among the actions which society expects from the individual and s/he has internalized, there are the roles attributed to man and woman. In the formation of the social gender roles, the action types attributed to genders, duties and responsibilities are in the foreground.

The individual is not born with attitudes and behaviors attributed to the genders. S/he learns these attitudes and behaviors in a certain society. However, the roles attributed to men and women can differ from society to society. Because each society has different culture, traditions and customs. This situation has a great effect on the formation of personality. To the that extent that, society does not find the development of an individual sufficient who does not comply with its expectations. Gender stereotypes of a society have a great impact on the personality development of a child. One of the places where these stereotypes are imposed to the child is school.

Schools have a major impact on strengthening or weakening social gender roles. Schools use various methods, techniques and tools in order to gain students the goals of society's expectations. One of these tools is textbooks. Textbooks have a great effect on the formation of gender roles in students. Because the teacher takes the textbook as the basis for the educational activities in the classroom. The student makes use of the textbook most of his time in the classroom. In this context, textbooks are effective in the development of the child and gaining social gender roles.

Stereotypes, which vary from society to society and continue from the past to the present, have paved the way for the formation of gender roles. This situation paved the way for the formation of a patriarchal family structure in time and the woman was pushed into the background. In recent years, efforts to change this situation against women and to ensure equality of men and women have intensified. The reflection of gender roles in the choice of profession creates a disadvantage for women. Ensuring gender equality in all areas of society will accelerate the development of societies and eliminate many negative situations. This is possible with an effective education. In line with this information, it is important to evaluate textbooks in the context of gender roles. Investigating the situation and attitude of other countries on this issue will also contribute to the relevant literature.

\section{Methodology}

This study, which aims to examine the visuals in the French middle school History and Geography textbooks in the context of gender roles, was carried out with the document analysis, which is one of the qualitative research methods. In this context, the sample of the 
study consists of the 5th, 6th, 7th and 8th grade History and Geography textbooks of the middle school being taught in France in the 2020-2021 academic year. These textbooks cover the topics of history, geography and citizenship. The research data were collected through document analysis and the obtained data was analyzed with the content analysis technique.

\section{Findings, Conclusion and Discussion}

In the study, the visuals in the textbooks were examined in the context of gender roles, and findings regarding male and female roles, parental roles and professional roles were obtained. Based on these findings, the following results were reached in the study:

As a result of examining the visuals in the French secondary school History and Geography textbooks in the context of the roles of parents; It is observed that women are mostly engaged in domestic work, child cleaning, childcare and child education, and they take on the tasks of preparing the needs such as cleaning the house and preparing food and beverage, which are another domestic activity. Men, on the other hand, are observed to earn a living by dealing with agriculture and land, and by working outside the home. This situation shows that women are mostly depicted in indoor settings, while men are depicted in outdoor settings. As a result of examining the visuals in the textbooks in the context of professional roles; It is observed that women are mostly associated with professions such as housewife and teaching, while men are associated with professional roles such as soldier, pilot, politician, farmer, architect/contractor and judge. In this context, it is seen that the number of professions attributed to women is more limited compared to the professions attributed to men. In short, it is seen that generally there are important differences in the context of male-female roles in the visuals in the textbooks and this situation has a significant effect on the roles of parents and occupational roles.

The findings obtained in the study were compared with domestic and international studies on the subject and it was observed that the existing situation was mostly similar. In these studies, it was found that female gender is generally associated with domestic work, while males are associated with out-of-home environments; It is seen that only professions such as housewife and teaching are attributed to women, while professions such as politicians, administrators, architects, judges and prosecutors are attributed to men. This general approach reveals that significant differences are created between male and female genders in the context of gender roles through the visuals in the textbooks.

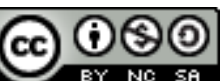

"International Journal of New Approaches in Social Studies - IJONASS" is licensed under a Creative Commons Attribution-NonCommercial-ShareAlike 4.0 International License. 